\title{
An Overview to the Health Benefits of Seaweeds Consumption
}

\author{
Silvia Lomartire ${ }^{1}$, João Carlos Marques ${ }^{1}$ and Ana M. M. Gonçalves ${ }^{1,2, *(D)}$ \\ 1 University of Coimbra, MARE-Marine and Environmental Sciences Centre, Department of Life Sciences, \\ Calçada Martim de Freitas, 3000-456 Coimbra, Portugal; silvia.lomartire@uc.pt (S.L.); \\ jcmimar@ci.uc.pt (J.C.M.) \\ 2 Department of Biology and CESAM, University of Aveiro, 3810-193 Aveiro, Portugal \\ * Correspondence: amgoncalves@uc.pt; Tel.: +351-239-240-700 (ext. 262-286)
}

check for updates

Citation: Lomartire, S.; Marques, J.C.; Gonçalves, A.M.M. An Overview to the Health Benefits of Seaweeds Consumption. Mar. Drugs 2021, 19, 341. https://doi.org/10.3390/ md19060341

Academic Editor: Diana Cláudia Pinto

Received: 1 May 2021

Accepted: 8 June 2021

Published: 15 June 2021

Publisher's Note: MDPI stays neutral with regard to jurisdictional claims in published maps and institutional affiliations.

Copyright: (c) 2021 by the authors. Licensee MDPI, Basel, Switzerland. This article is an open access article distributed under the terms and conditions of the Creative Commons Attribution (CC BY) license (https:/ / creativecommons.org/licenses/by/ $4.0 /)$.

\begin{abstract}
Currently, seaweeds are gaining major attention due to the benefits they give to our health Recent studies demonstrate the high nutritional value of seaweeds and the powerful properties that seaweeds' bioactive compounds provide. Species of class Phaeophyceae, phylum Rhodophyta and Chlorophyta possess unique compounds with several properties that are potential allies of our health, which make them valuable compounds to be involved in biotechnological applications. In this review, the health benefits given by consumption of seaweeds as whole food or by assumption of bioactive compounds trough natural drugs are highlighted. The use of seaweeds in agriculture is also highlighted, as they assure soils and crops free from chemicals; thus, it is advantageous for our health. The addition of seaweed extracts in food, nutraceutical, pharmaceutical and industrial companies will enhance the production and consumption/usage of seaweed-based products. Therefore, there is the need to implement the research on seaweeds, with the aim to identify more bioactive compounds, which may assure benefits to human and animal health.
\end{abstract}

Keywords: seaweeds; bioactive compounds; human health; pharmaceutical application; nutraceutical application

\section{Introduction}

Seaweeds are considered a nutrient-rich food as they are a good source of minerals, vitamins ( $\mathrm{A}, \mathrm{B}_{1}, \mathrm{~B}_{2}, \mathrm{~B}_{9}, \mathrm{~B}_{12}, \mathrm{C}, \mathrm{D}, \mathrm{E}$, and $\mathrm{K}$ ), essential minerals (calcium, iron, iodine, magnesium, phosphorus, potassium, zinc, copper, manganese, selenium, and fluoride), dietary fibers [1-4], protein, essential amino acids and polyphenols, which exhibit antioxidant and anti-inflammatory properties [5]. Seaweeds possess a low lipid content, nonetheless enriched in polyunsaturated fatty acids. This characteristic makes them even more attractive, as they are a healthy, nutritive and low-caloric food [2]. Seaweeds were consumed as whole food since ancient times, and they still have great economic importance. Saccharina spp. with Porphyra spp. and Undaria pinnatifida (Phaeophyceae) are the three algae mainly consumed in Asian meals [6].

Seaweed bioactive compounds are also employed in biomedical and pharmaceutical industries as they possess antitumoral activity against some type of cancer cell lines, but they do not affect negatively healthy cells, as it happens with current antitumoral treatments $[7,8]$. Phycocolloids, which derive from brown and red algae, are used in the food industry (gelling agents), pharmaceuticals (dressings, coatings of medicaments) and biotechnology (culture medium, the Petri dishes). They are also found in cosmetics (body lotions, soaps, shampoos, toothpaste) [9]. Marine algae have been traditionally used in animal feed and in agriculture and production of biodiesel.

Seaweeds are classified as brown, red or green algae, and for each group are present diverse bioactive compounds with multiple properties which may be exploited for biotechnological applications. Phaeophyceae (brown algae) have been consumed as whole food for a long time in Asian countries; however, scientists have only recently gained an understanding of the reasons behind the positive effects that seaweed bioactive compounds have 
on our health. Brown algae possess fucoidans that are already available in the market as nutraceutical products, since they exhibit antibacterial [10], antiviral [11] anti-inflammatory, anticoagulant, and antithrombotic effects [12]. Rhodophyta (red algae) extracts are widely exploited in medical and pharmaceutical sectors, particularly carrageenans and agar. Agar is used in biomedicine as suspension component in drug solutions and in prescription products, but also as anticoagulant agents [13]. Carrageenans can be exploited for the production of antitumoral therapies, due to their antitumor immunity activation [7]. Chlorophyta (green algae) are rich in ulvan, a sulphate polysaccharide commonly used in biomedicine, cosmetic and pharmaceutical industries but also as emulsifiers, stabilizers, and thickeners in food products [14].

The human health benefits from seaweeds can be through direct and indirect way: through the consumption of the whole seaweed or the uptake by assumption of food supplement or natural drugs (direct health benefits) or by using seaweeds in agriculture as natural fertilizers, in order to have a nutrient soil and healthy cultivation without the presence of chemicals contained in traditional fertilizers. Thus, the use of seaweeds as biofertilizers will enhance the plants and soil conditions [15-17], giving positive effects to our health after agriculture products consumption (indirect health benefits).

In this review, the applications regarding seaweeds extracts are highlighted, with specific attention given to the health benefits of specific bioactive compounds. Therefore, further studies have to be performed in order to achieve deep knowledge about these powerful sources of nutrients and biological compounds.

\section{Main Bioactive Compounds of Seaweeds}

Seaweeds are rich in several bioactive compounds such as polyphenols, sterols, alkaloids, flavonoids, tannins, proteins with essential amino-acids, polyunsaturated fatty acids, etc. [13]. These bioactive compounds provide not only protection to seaweeds, but also a high nutritional value and several benefits for humans. For example, polysaccharides from seaweeds have a positive effect on intestinal tract, but contrary to fibres, they are free of calories [2]. Agar and carrageenan, extracted from red algae, and alginates, extracted from brown algae, are commonly employed in food and pharmaceutical products as stabilizers [18].

Due to their beneficial properties, these biological compounds extracted from marine algae have been received attention from researchers. These compounds might be employed for creation of novel and functional food but also for pharmaceutical and biomedical applications [19].

\subsection{Phaeophyceae}

The main compounds useful for biotechnological applications present in brown seaweeds are mentioned in Table 1.

The typical brown colour of Phaeophyceae is due the presence of a particular pigment called fucoxanthin (Figure 1) [20,21], which structure varies among species [22]. Studies showed that fucoxanthins have antitumoral, antioxidant and anti-obesity properties [23-25].

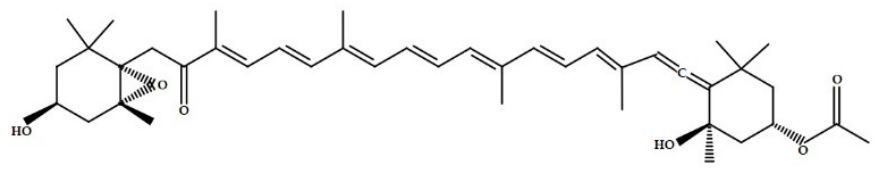

Figure 1. Chemical structure of fucoxanthin.

In brown algae, laminaran and fucoidan are mostly interesting for their potential biological activities, while alginate is mostly used as food ingredients. In particular, fucoidans and laminarans contents may vary from species to species from $20 \%$ to $50 \%$ of algae dry weight [26]. 
The sulphate polysaccharide (SP) fucoidan (Figure 2) presents a skeleton that is rich in fucose. This SP is present in high quantity; indeed, fucoidans may constitute up to $25-30 \%$ of the algae dry weight, depending on the seaweed species and on season $[27,28]$. The fucoidan structure is highly branched with specific sugars bonds [29-31] which can vary among species [30,32]. Fucoidans in seaweeds are indeed heterogenic; they present variations in terms of carbohydrate-unit content and content of sulphate and acetyl groups. Depending on the structure of the main chain, fucoidans may be sulphated at C4, C2 or both $\mathrm{C} 2$ and $\mathrm{C} 4$ positions of fucose units $[28,33,34]$. Some fucoidans may be both sulphated and acetylated $[33,35]$. The position and content of sulphate groups are important to the biological activities of SPs; thus, it is important to determine the structure of fucoidans in brown seaweeds. The methods of determining the sulphate position include infrared spectroscopy, desulfation, stability of sulphate esters to alkali and methylation analysis [30].

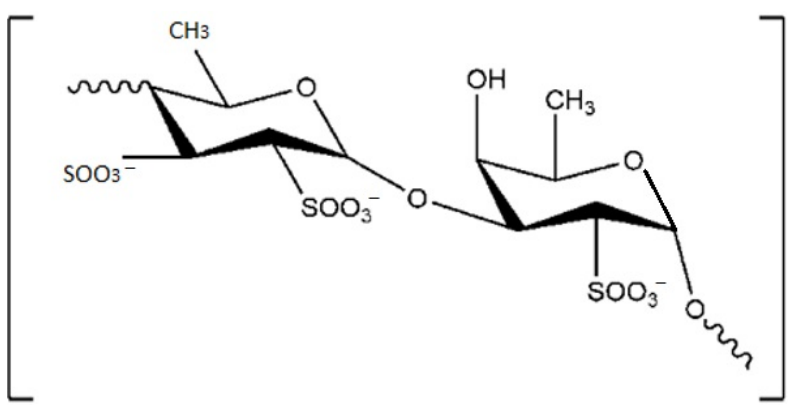

Figure 2. Chemical structure of sulphate polysaccharide (SP) fucoidan.

In terms of polysaccharides, the most specific one is the alginic acid, also called algin or alginate (Figure 3). These polysaccharides can be extracted from cell walls of brown algae including Macrocystis pyrifera, Laminaria hyperborea, Ascophyllum nodosum, and various bacterial strains [36]. Alginate can constitute between $10 \%$ and $40 \%$ of the dry weight (untreated) of the algae; $30-60 \%$ of the total sugars in brown seaweeds is composed by alginates [37]. The structure of alginic acid consists of a linear polysaccharide of 1,4-linked $\beta$-D-mannuronic acid $(\mathrm{M})$ and 1,4 $\alpha$-L-guluronic acid $(\mathrm{G})$ residues arranged in homogenous (poly-G, poly-M) or heterogeneous (MG) block-like patterns [38]. Properties such as biodegradability, biocompatibility, non-toxic behaviour, and low cost would render alginates excellent candidates in biological applications [39]. Sources of alginates have been found in Ascophyllum spp., Durvillaea spp., Laminaria spp., Lessonia spp., Macrocystis spp., Sargassum spp. and Ecklonia radiata [40]. Fucales (large brown seaweed) also utilized for nutrition and alginates, include Scytothalia dorycarpa, Cystophora subfarcinata and Sargassum linearifolium [40].

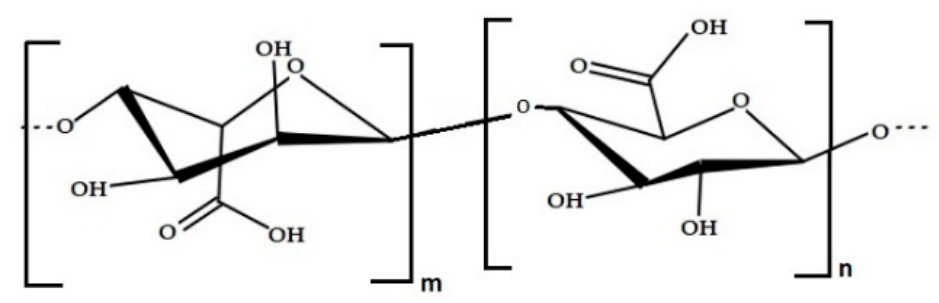

Figure 3. Chemical structure of alginic acid.

Laminarans possess structures and composition that vary according to algae species [35]. These molecules are composed of (1,3)- $\beta$-D-glucan [26] with $\beta-(1,6)$ branching [41] (Figure 4). There are two types of laminaran chains ( $M$ or $G)$, which differ in their reducing end. $M$ chains end with a mannitol residue, whereas $G$ chains end with a glucose residue. Laminarans molecular weight is approximately $5000 \mathrm{Da}$. This molecule contains a high number of neutral sugars and low quantity of uronic acids. Presence of laminar molecules has been detected in Saccharina longicruris, Ascophyllum nodosum and Fucus vesiculosus [42]. 


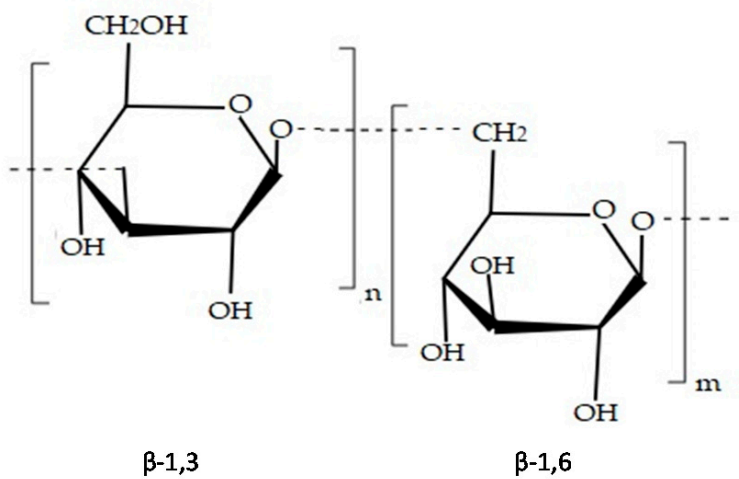

Figure 4. Chemical structure of laminaran.

Regarding polyunsaturated fatty acids (PUFAs), brown seaweeds are mainly composed of linoleic acid (C18:2n-6, LA), arachidonic acid (C20:4n-6, DHA) and eicosapentaenoic acid (C22:5n-3, EPA) [43,44]. Cholesterol is one of the major sterols presented in all groups of seaweed [45]. Besides that, brown and green algae are rich in other C29 sterols, particularly fucosterol and isofucosterol, respectively [46,47].

Table 1. Biological compounds isolated from Phaeophyceae.

\begin{tabular}{cccc}
\hline Type of Algae & Isolated Compounds & Type of Compound & Reference \\
\hline \multirow{3}{*}{ Phaeophyceae } & Laminaran & Polysaccharide of glucose & {$[26,41,42]$} \\
\cline { 2 - 4 } & Fucoidan & Sulphated polysaccharide & {$[28-31]$} \\
\cline { 2 - 4 } & Alginic acid & Polysaccharide & {$[38,39]$} \\
\cline { 2 - 4 } & Phlorotannin & Polyphenolic compound & {$[48-52]$} \\
\cline { 2 - 4 } & Fucoxanthin & Pigment & {$[22-25]$} \\
\hline
\end{tabular}

Phlorotannins are very specific polyphenols present in brown algae. Their presence and activity in algae vary depending on species and environmental conditions. The biological functions of phlorotannins are to protect seaweeds from UV radiations, stress and herbivory but also to contribute to the cell wall resistance [48-50]. The structure of phlorotannin consist in phloroglucinol (1,3,5-trihydroxybenzene) units that are bonded to each other by different pathways. They are found in the range 126-650 kDa, and their concentration in dried brown seaweeds varies from $0.5 \%$ to $2.5 \%$ [51,52]. The biological activities exerted by phlorotannins are multiple, including anticancer [53] antioxidant [54], anti-inflammatory [55] antidiabetic, and neuroprotective [56] activities. This suggests that these compounds are potentially useful as new ingredients in food [57,58], animal feed, and pharmaceutical industries. Among brown seaweeds, Ecklonia cava has been reported to produce higher concentrations of phlorotannins than other marine phenolic compounds [59]. Ecklonia cava contains triphlorethol A, fucodiphlorethol G, dieckol, dioxinodehydroeckol, phloroglucinol eckol and phlorofucofuroeckol A (Figure 5A,B) [53], and they also exhibit antihypertensive [60] effects.

Eisenia bicyclis, Eisenia arborea, Ecklonia cava, Ecklonia kurome, Ecklonia stolonifera, Pelvetia siliquosa, and Ishige okamurae contain phlorotannins with antidiabetic, antioxidant, antitumor, anti-inflammatory, and anticancer properties [61]. Phlorofucofuroeckol A extracted from Eisenia arborea showed antiallergic effects [62]. 
<smiles></smiles>

(A)

(B)

Figure 5. Chemical structure of eckol (A) and phlorofucofuroeckol A (B), phlorotannins isolated from Ecklonia cava.

\subsection{Rhodophyta}

Marine red algae produce high quantity of secondary metabolites [63], including sesquiterpenes, diterpenes, triterpenes and many other types that exert various biological activities such as antifungal, antibacterial, and anticancer activities [64].

The main compounds useful for biotechnological applications present in red seaweeds are mentioned in Table 2.

Carrageenans are SPs present only in red algae [7]. Their structure is constituted by SPs (galactans), which can form gels in water or milk solutions. This phycocolloid is used mainly in food, cosmetic and pharmaceutical industry. Tests on carrageenans demonstrated that they express immune stimulating, antioxidant, anticoagulant antitumoral and antiviral properties $[65,66]$, which make red algae extracts commercially exploited $[13,67]$. These natural polysaccharides are a mix of sulphated linear galactans and their structural units are presented with the disaccharides of $\alpha-(1 \rightarrow 4)$-linked D-galactopyranose (D) residue or 3,6-anhydrogalactopyranose (DA) and $\beta$ - $(1 \rightarrow 3)$-linked D-galactopyranose $(\mathrm{G})$ residue. Sulphate groups are covalently linked via ether bonds to the carbohydrate atoms C-2, C-4 or C-6 of galactose [7]. Usually, k-carrageenans (Figure 6) available in the market are extracted from Kappaphycus alvarezii using the hot extraction processing, while $\lambda$-carrageenans are commonly isolated from red algae belonging to the genera Gigartina or Chondrus with the use of drum dryer procedure or ethanol precipitation [68]. These SPs have been found in the families Solieriaceae, Rhabdoniaceae, Phyllophoraceae, Gigartinaceae, Rhodophilidaceae, and Thichocarpaceae. Eight sources of carrageenans were discovered exclusively in the Japanese sea (East Sea), and five of them (Chondrus pinnulatus, Chondrus armatus, Chondrus yendoi, Mastocarpus pacificus, Mazzaella hemisphaerica) belong to the Gigartinaceae and Solieriaceae. In addition to Gigartinaceae, high carrageenan contents were found in the algae of the families Phillophoraceae and Thichocarpaceae, species of which are widely spread in all far eastern seas [7]. 


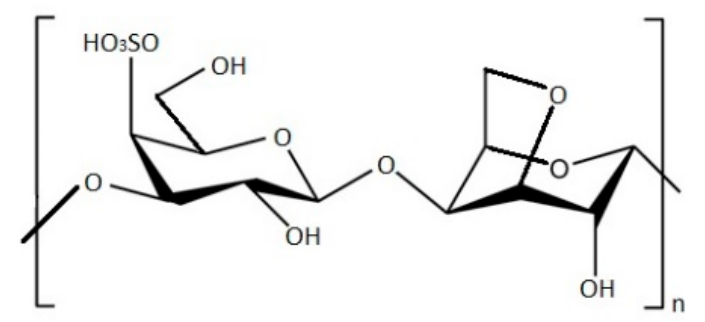

Figure 6. Chemical structure of $\mathrm{k}$-carrageenan.

Table 2. Biological compounds isolated from Rhodophyta.

\begin{tabular}{cccc}
\hline Type of Algae & Isolated Compounds & Type of Compound & Reference \\
\hline & $\begin{array}{c}\text { Carrageenans } \\
\text { Agar }\end{array}$ & $\begin{array}{c}\text { Sulphated } \\
\text { polysaccharides }\end{array}$ & {$[7,65,66]$} \\
\cline { 2 - 4 } Rhodophyta & Sesquiterpenes & $\begin{array}{c}\text { Mixture of } \\
\text { polysaccharide agarose } \\
\text { and small molecules } \\
\text { Terpenes }\end{array}$ & {$[69-72]$} \\
\cline { 2 - 4 } & Diterpenes & Terpenes & {$[63,64]$} \\
\cline { 2 - 4 } & Triterpenes & Terpenes & {$[63,64]$} \\
\hline
\end{tabular}

Agar is a collective term used to describe a mixture of gelling polysaccharides made up of D-galactose and L-galactose [69]. This mixture is synthesized in the cell wall matrix of red seaweeds. It remains in the form of gel under ambient temperature [70]. The polysaccharide that presents repeated D-galactose and 3,6-anhydro-L-galactose units joined by $\beta-1,3-$ and $\alpha-1,4-$ glycosidic bonds is commonly known as agarose (Figure 7) [71], which contribute up to $70 \%$ of agar polysaccharide.

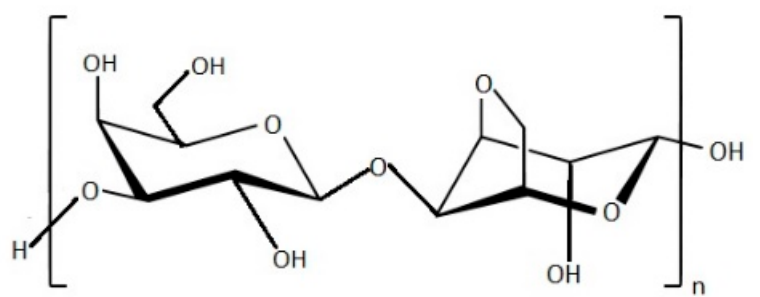

Figure 7. Chemical structure of agarose polymer.

Agar and other polysaccharides provide resistance to pathogens, maintain cellular ionic equilibrium, protect algae against extreme salinity, $\mathrm{pH}$ and temperature, and desiccation $[9,72]$.

Moreover, diverse agars are implied in different applications as phycocolloids in food, pharmaceuticals, cosmetic, medical and biotechnology industries. Global production of agar has escalated from 6800 tons (USD 82.2 million) in 2002 to 9600 tons (USD 173 million) in 2009, with Gracilaria spp. (80\%) and Gelidium spp. (20\%) as the largest agar industrial sources [73], reported as the species with highest sulfation degree [74]. Gracilaria spp. agars with lower gel strength have gained more attention due to depleted Gelidium spp. stocks and the successful cultivation of Gracilaria $[75,76]$.

\subsection{Chlorophyta}

The main compounds useful for biotechnological applications present in green seaweeds are mentioned in Table 3. 
Chlorophyta present their typical green colour due to the presence of chlorophylls ( $a$ and $b$ ) and carotenoids ( $\beta$-carotene and xanthophylls). Pigments in seaweeds are important because they possess antioxidant activity [77]; thus, they protect seaweeds against harmful effects experienced due to irradiance.

In terms of PUFAs, Chlorophyta are mostly composed by the C16 and C18 PUFA, namely the linoleic acid (LA; C18:2n-6) in most of the species. However, $\alpha$-linolenic acid (ALA, C18:3n-3) is characteristic of Ulvales [78-80]. Contrasting with red and brown algae, green algae also contain large amounts of palmitic (16:3n-3; 16:4n-3)) PUFAs. Regarding the carbohydrates, Chlorophyta are rich in SPs that constitute the cell walls [81]. The PUFA content of the green seaweed Ulva linza exhibited the best inhibitory activities against inflammatory response [82]. Monounsaturated fatty acid (MUFA) derivates extracted from Ulva lactuca have been discovered to induce many antioxidant-response elements which release antioxidant genes in various mouse tissues [83]. Moreover, seaweeds such as Codium spp., Ulva spp. and Chaetomorpha spp. possess other interesting compounds, for example the sterols 28-isofucosterol [79,84], ergosterol and 24-ethylcholesterol [85]. Green seaweeds possess high content of polysaccharides, for example the $65 \%$ of dry weight of Ulva spp. contains polysaccharides [86].

Table 3. Biological compounds isolated from Chlorophyta.

\begin{tabular}{cccc}
\hline Type of Algae & Isolated Compounds & Type of Compound & Reference \\
\hline \multirow{3}{*}{ Chlorophyta } & Ulvan & Sulphated polysaccharides & {$[87-89]$} \\
\cline { 2 - 4 } & Palmitic acid & Saturated fatty acid & {$[87-89]$} \\
\cline { 2 - 4 } & $\begin{array}{c}\text { Linoleic acid } \\
\text { Chlorophylls (a and b) }\end{array}$ & Polyunsaturated fatty acid & {$[78,80]$} \\
\cline { 2 - 4 } $\begin{array}{c}\text { Carotenoids } \\
\text { ( -carotene and } \\
\text { xanthophylls })\end{array}$ & Pigments & {$[77]$} \\
\hline
\end{tabular}

The most important SP extracted from cell wall of green seaweeds is ulvan. This compound, with fucoidan and carrageenan, has wide application in many fields, for example, in cosmetics formulations to produce hair conditioners, moisturizers, emulsifiers, wound-healing agents, and as a thickening agent [9]. Ulvan is generally present for 9-36\% dry weight of Ulva biomass $[87,88]$. The chemical structure of this SP is mainly composed of sulphated rhamnose, glucuronic acid, iduronic acid, and xylose and repeating disaccharide structure comprised of an uronic acid linked to a sulphated neutral sugar (Figure 8) [87]. Ulvan possesses antioxidant activities which makes it a potential candidate to be involved in diverse applications, such as pharmaceutical, agricultural, medical applications and production of alternative biomaterial [81,89].

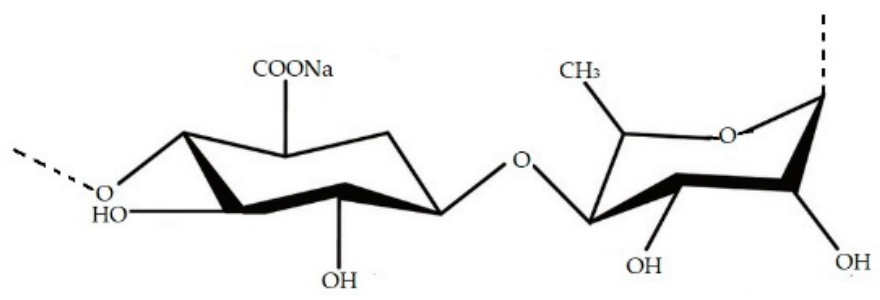

Figure 8. Chemical structure of ulvan.

\section{The Health Benefits of Seaweed Bioactive Compounds}

Seaweeds bioactive compounds are exploited in several biotechnological applications (Table 4). Due to their properties, these compounds can contribute to the development of biomedicine and modern pharmacy, in order to achieve new formulation based on components from natural origin. The consumption of seaweeds by food or trough natural 
drugs will contribute to the occurrence of a healthier lifestyle. Nutraceutical, biomedical and pharmaceutical applications that involve seaweeds' bioactive compounds are further showed.

Table 4. Main compounds of seaweeds involved in biotechnological applications.

\begin{tabular}{|c|c|c|c|c|}
\hline Seaweed & Main Bioactive Compound & Property & Biotechnological Application & Reference \\
\hline & & Phaeaophyceae & & \\
\hline Laminaria hyperborea & \multirow{9}{*}{ Alginate } & \multirow{9}{*}{$\begin{array}{l}\text { Biodegradability, biocompatibility, non-toxic } \\
\text { behaviour }\end{array}$} & \multirow{9}{*}{$\begin{array}{l}\text { Cosmetics, pharmaceutical and food } \\
\text { industries as stabilizers }\end{array}$} & \multirow{9}{*}[18,40]{} \\
\hline Ascophyllum nodosum & & & & \\
\hline Ecklonia radiata & & & & \\
\hline Durvillaea sp. & & & & \\
\hline Lessonia sp. & & & & \\
\hline Sargassum sp. & & & & \\
\hline Scytothalia dorycarpa & & & & \\
\hline Cystophora subfarcinata & & & & \\
\hline Sargassum linearifolium & & & & \\
\hline \multirow[t]{2}{*}{ Macrocystis pyrifera } & Alginate & $\begin{array}{l}\text { Biodegradability, biocompatibility, non-toxic } \\
\text { behaviour }\end{array}$ & Cosmetics as a thickening agent & [36] \\
\hline & Phlorotannins & Antioxidant activity & Cosmetics for preventing skin aging & {$[90]$} \\
\hline Ecklonia cava & Phlorotannins & $\begin{array}{c}\text { Anticancer, antioxidant, anti-inflammatory, } \\
\text { antiviral activities and antihypertensive } \\
\text { effects. }\end{array}$ & $\begin{array}{l}\text { Pharmaceutical and nutraceutical } \\
\text { industries }\end{array}$ & {$[49,50,53]$} \\
\hline Eisenia arborea & Phlorotannins & Antiallergic effects & Pharmaceutical industry & {$[62]$} \\
\hline Eisenia bicyclis & \multirow{5}{*}{ Phlorotannins } & \multirow{5}{*}{$\begin{array}{c}\text { Antidiabetic, antioxidant, antitumor, } \\
\text { anti-inflammatory, and anticancer activities }\end{array}$} & \multirow{5}{*}{$\begin{array}{l}\text { Pharmaceutical and medical } \\
\text { industries }\end{array}$} & \multirow{5}{*}[61]{} \\
\hline Ecklonia kurome & & & & \\
\hline Ecklonia stolonifera & & & & \\
\hline Pelvetia siliquosa & & & & \\
\hline Ishige okamurae & & & & \\
\hline Fucus vesiculosus & Phlorotannins & Anti-inflammatory and antioxidant properties & $\begin{array}{l}\text { Cosmetics, to produce make-up and } \\
\text { sunscreens }\end{array}$ & [91] \\
\hline Fucus evanescens & \multirow{2}{*}{ Fucoidans } & \multirow{2}{*}{ Anticoagulant activity } & \multirow{2}{*}{ Potential substitute to heparin } & \multirow{2}{*}[92,93]{} \\
\hline Laminaria cichorioides & & & & \\
\hline \multicolumn{5}{|c|}{ Rhodophyta } \\
\hline Chondrus pinnulatus & \multirow{3}{*}{$\begin{array}{l}\lambda \text {-carrageenan and } \\
\mathrm{K} \text {-carrageenan }\end{array}$} & \multirow{3}{*}{ High viscosity in drinks; antitumoral property } & \multirow{3}{*}{$\begin{array}{l}\text { Food industry (production of drinks, } \\
\text { e.g., milk and chocolate) and } \\
\text { pharmaceutical industry }\end{array}$} & \multirow{3}{*}[7,73]{} \\
\hline Chondrus armatus & & & & \\
\hline Chondrus yendoi & & & & \\
\hline Kappaphycus striatum & K-carrageenan & $\begin{array}{l}\text { Antitumoral activity against human } \\
\text { nasopharynx carcinoma, human gastric } \\
\text { carcinoma, and cervical cancer cell lines }\end{array}$ & Pharmaceutical industry & [94] \\
\hline Kappaphycus alvarezii & K-carrageenan and agar & Antioxidant properties & $\begin{array}{l}\text { Cosmetics and nutraceutical } \\
\text { industry }\end{array}$ & {$[68,95]$} \\
\hline Gracilaria edulis & $\begin{array}{l}\text { Agar } \\
\text { Phenolic, flavonoid, and } \\
\text { alkaloid compounds }\end{array}$ & $\begin{array}{l}\text { Antidiabetic, antioxidant, antimicrobial, } \\
\text { anticoagulant, anti-inflammatory, and } \\
\text { antitumoral activities; hypoglycaemic activity }\end{array}$ & Pharmaceutical industry & {$[74,96-98]$} \\
\hline Laurencia catarinensis & Halogenated metabolites & Antitumoral activity & Pharmaceutical industry & [99] \\
\hline Laurencia obtuse & Diterpene and sesquiterpene & $\begin{array}{l}\text { Actions against different cancer cell lines (KB, } \\
\text { HepG2 and MCF-7) }\end{array}$ & Pharmaceutical industry & [99] \\
\hline Griffithsia sp. & Griffith (Protein) & $\begin{array}{l}\text { Antiviral activity against MERS-CoV-2 virus } \\
\text { and SARS-CoV-2 glycoprotein }\end{array}$ & Pharmaceutical industry & {$[100,101]$} \\
\hline \multicolumn{5}{|c|}{ Chlorophyta } \\
\hline Caulerpa racemosa & $\begin{array}{l}\text { Phenolic compounds and } \\
\text { flavonoids }\end{array}$ & $\begin{array}{l}\text { Antioxidant, scavenging, anti-proliferative } \\
\text { activities of cancer line cells }\end{array}$ & $\begin{array}{l}\text { Pharmaceutical and nutraceutical } \\
\text { industries }\end{array}$ & {$[102,103]$} \\
\hline Ulva lactuca & Ulvan & $\begin{array}{c}\text { Antioxidant activity, antimicrobial and } \\
\text { photocatalytic activities }\end{array}$ & $\begin{array}{l}\text { Food industry (the whole body is } \\
\text { used as salad) and industrial } \\
\text { industry (production of biogas and } \\
\text { biodiesel) }\end{array}$ & $\begin{array}{l}{[83,103-} \\
106]\end{array}$ \\
\hline Ulva rigida & Ulvan & $\begin{array}{l}\text { Antigenotoxic activity in human lymphocytes; } \\
\text { hypoglycaemic effect in vivo experiment }\end{array}$ & Pharmaceutical industry & {$[107,108]$} \\
\hline Ulva fasciata & Ulvan & $\begin{array}{l}\text { Antioxidant and good mechanical properties; } \\
\text { antiviral property }\end{array}$ & $\begin{array}{l}\text { Industrial industry to develop } \\
\text { bioplastics; pharmaceutical industry }\end{array}$ & {$[109,110]$} \\
\hline
\end{tabular}




\subsection{Nutraceutical Applications}

It is identified as "nutraceutical food" a food that provides not only nutritional value but also it may help to prevent health problems. Seaweeds-based foods are considered nutraceutical products due to the positive effects on human health, for example, to alleviate arthritis, diabetes, autoimmune, ocular and cardiovascular diseases [102].

Phaeophyceae has been consumed as whole food for a long time in Asian countries. Currently, seaweed extracts are receiving more attention. Fucoidan is the main component of brown algae with a broad spectrum of action, the effect of which depends on various factors, including molecular weight, as Dörschmann and Klettner [111] highlighted. For example, the positive angiogenesis activity exerts by fucoidans mostly depend on the molecular weight of the fucoidan: with low-molecular-weight fucoidans are generally considered to be pro-angiogenic, while fucoidans with high-molecular-weight fucoidans are considered to be antiangiogenic [112]. High-molecular-weight fucoidans have been discovered to enhance the viability and prevents the death of spleen cells [113].

Fucoidans present in some brown seaweed species are commercially available as nutraceutical products in Australia and the USA, since they express several biological activities after the uptake, including antibacterial [10], antiviral [11] anti-inflammatory [12], anticoagulant, antithrombotic [12], antidiabetic [114], procoagulant [115], anticancer [116] and antiviral activities [117]. Currently, fucoidans can be considered promising molecules for biomedical application; therefore, they are still not approved for medical applications $[118,119]$. Tests were carried out to detect the anticoagulant activity of fucoidan. Fucoidans isolated from Fucus vesiculosus were injected on mice. After a single-dose oral administration, the anticoagulant activity was established with the anti-Xa assay, a laboratory test which indirectly measures the activity of heparins [120].

Moreover, the chemical diversity of fucoidan and its antioxidant capacity can contribute to the prevention of human diseases $[12,121,122]$ such as cancer, diabetes, Alzheimer's disease, Parkinson's disease and AIDS [22,123,124]. For example, fucoidan from Cladosiphon okamuranus showed in vivo apoptotic activity in mice cancer cells enhancing anti-proliferative activity without any negative consequence of normal epithelial cells [125]. Fucoidans with low molecular weight extracted from Lonicera japonica exhibited reduced diabetic retinopathy during in vivo test, decreasing the high-glucose-induced proliferation in cells and the retinal neovascularization and retinal damage as well [126]. Trinchero et al. [127] tested fucoidans isolated from Adenocystis utricularis that showed in vitro antiviral property against HIV-1 trough prevention of HIV-1 replication. Phlorotannins are already available in the market as food supplements and functional food ingredients [57,58]. The European Food Safety Authority (EFSA) Panel on Dietetic Products, Nutrition and Allergies (NDA), pursuant to Regulation (EC) No. 258/97, announced that novel food supplements from phlorotannins (marketed as SeaPolynolTM) are safe for human consumption [57].

In the food industry, the carrageenan application is regulated by the Commission Regulation (EU) No 231/2012 in Europe, which states that commercial carrageenan (E 407) fundamentally involves potassium, sodium, magnesium, and calcium sulphate esters of galactose and 3,6-anhydrogalactose polysaccharides [128]. The commercial form of agar approved for food industry by the Food and Drugs Administration (FDA) and the European Food Safety Agency (EFSA), in Europe is coded E-406 by the Commission Regulation No 257/2010 [129].

Agar is widely employed in biotechnological and research sectors, for example to produce biological culture media. However, low-quality agar is used in food products such as candies, fruit juice, frozen foods, bakery icing, or meringues [13]. Porphyra/Pyropia spp., Eucheuma spp., Kappaphycus alvarezii, and Gracilaria spp. (Rhodophyta) are the species most cultivated for exploitation of hydrocolloid for food industry [95].

The $\lambda$-carrageenan and $k$-carregeenan of fam. Gigartinaceae are special type of carrageenan which are in the market as they generate quality and exhibit high viscosity in drinks, such as milk with chocolate [73]. The species most exploited for agar extractions belong to the genera Gelidium, Gracilaria and Pterocladiella [130]. 
Red algae are also rich in minerals and vitamins useful for our health. Palmaria palmata (Rhodophyta) contains high values of vitamin $C$ that facilitates the absorption of iron, phycoerythrin a precursor to vitamin A, and trace of iron, potassium, and iodine that represent the $30 \%$ of its dry weight, while the $18 \%$ of the weight represents proteins of high nutritional value [131]. Another advantage of red algae assumption is the uptake of calcium for our organisms. It has been analysed the presence of calcium in Chondrus crispus (Rhodophyta), commonly known as Irish moss, and compared it with the calcium concentration present in the milk, which was lower [132].

Chlorophyta has been used as food source since long time. Caulerpa spp. is consumed as "seagrape" while Ulva spp. is consumed as whole food in salads [103]. Bioactive compounds of green seaweeds possess antioxidant, anticoagulant, antimutagenic, antibacterial, and anticancer activities [133]; thus, they have the potential to be functional foods. Ulva lactuca (Chlorophyta) extracts showed antimicrobial and photocatalytic activities [106]. The polysaccharide ulvan has been developed as a vegan alternative to beef-derived gelatine [134]. Caulerpa spp., especially Caulerpa racemosa (Chlorophyta), was found to be rich in phenolic and flavonoid compounds such as cyanidin, malvidin, quercetin, kaempferol, and apigenin. These metabolites are responsible for the high biochemical (antioxidant, scavenging, and reducing) and anti-proliferative activities of cancer line cells. Moreover, nutritional antioxidants and metabolites, make Caulerpa racemosa a promising functional food [102].

\subsection{Biomedical Applications}

Seaweeds bioactive compounds possess properties which make them attractive for biomedical applications.

Long time before the scientific research knowledge, many species of seaweeds have been used in traditional medicine, especially in Asian countries against goitre, nephritic diseases, anthelmintic, catarrh, just to new few diseases as medicaments or as pharmaceutical auxiliaries [135]. Among brown seaweeds Laminaria spp. was employed mainly in Japanese folk medicine for lowering the blood pressure, while Fucus vesiculosus has been used as a medicinal drug, mainly on account of its iodine content, for obesity defects and goitre [135], for the treatment of sore knees [136], healing wounds [137] and also as herbal teas for their laxative effects [138].

Carrageens of Chondrus crispus (Rhodophyta) have been used for a long time as a medicinal drug as a mucilage against diarrhoea, dysentery, gastric ulcers and as a component of numerous health teas, for example, for colds. Gelidium cartilagineum (Rhodophyta) has been used in Japan for colds and scrofula in paediatric medical science [135]. Ulva lactuca (Chlorophyta) has been used in folk medicine for gout and as astringent [135].

Extracts of Rhodophyta are very promising natural compounds to be exploited in biomedicine. Many species of Asian seaweeds are used as traditional medicine, such as Gracilaria spp. (Rhodophyta) which are used as laxative, Sargassum spp. (Phaeophyceae) are used to cure Chinese influence, while Caloglossa spp., Codium spp., Dermonema spp. and Hypnea spp. (Rhodophyta) are used as vermifuge drugs [139].

The biological activities of carrageenans make these compounds potential candidates for new antitumoral therapies, due to their antitumor immunity activation [7]. For example, Kappaphycus species (Rhodophyta) are used to reduce ulcers, headaches and the incidence of tumours [139]. K-carrageenans isolated from Kappaphycus striatum demonstrated antitumoral activity against human nasopharynx carcinoma, human gastric carcinoma, and cervical cancer cell lines [94]. Different species belonging to the genus Laurencia (Rhodophyta) were tested to verify the bioactivity of their compounds. Some halogenated metabolites of Laurencia papillosa showed in vitro activity against human tumour cells Jurkat (acute lymphoblastic leukemia) [99]. Extracts of Laurencia obtuse, particularly in three different sesquiterpenes, have been isolated and evaluated against Ehrlich ascites carcinoma cells. The results showed antitumoral activity of the sesquiterpenes against 
Ehrlich ascites cells [140]. Ethanol extracts of Gracilaria edulis showed anticancer activity against ascites tumors in mice [97].

Undaria pinnatifida (Phaeophyceae) have anti-inflammatory properties that can be used as medicine to women after childbirth. This alga can also be used to lower fever, cure edema, and as a diuretic. Celikler et al. [107] surveyed the in vitro antigenotoxic activity in human lymphocytes from extracts of Ulva rigida (Chlorophyta). Although the antigenotoxic activity itself is not accentuated, these extracts possess strong protective effects against chemotherapeutic agent mitomycine-C.

During the past decade, studies suggested the use of seaweeds to prevent neurogenerative diseases [141]. The most common are Alzheimer's disease (AD), Parkinson's disease, Huntington's disease, and Amyotrophic Lateral Sclerosis (ALS) [142].

Several studies highlight the use of algal polysaccharides for the treatment of neurodegenerative diseases as referred by Bauer et al. [143]. Park et al. [144] demonstrated improved memory and learning in mice treated with fucoidan extracts from Ecklonia cava; thus, the study suggests promising results in future human trials [144]. Mice treated with polysaccharide extracted from Sargassum fusiforme also showed improved memory and improved cognition, compared to the control group [145]. Phlorotannins of Ecklonia cava, in particular dieckol and phlorofucofuroeckol, are related with the increment of major central neurotransmitters in the brain, particularly of Acetylcholine (ACh) [146]. Eisenia bicyclis phlorotannins have been studied by Ahn et al. [147]; the authors demonstrated that 7-phloroeckol and phlorofucofuroeckol A were potent neuroprotective agents against induced cytotoxicity, while eckol exhibited a weaker effect [147].

$\kappa$-carrageenans extracted from red algae have been also discovered can significantly reduce the rate of apoptosis induced by A $\beta 25-35$ on SH-SY5Y cells, supporting the hypothesis $\mathrm{K}$-carrageenans possesses neuroprotective properties; thus, they could be exploited as potential therapeutic agent for the treatment of AD [148].

Sulphated polysaccharides isolated from the green algae Codium fragile have been recently investigated from Wang et al. [149] to verify the protection against hydrogen peroxide ( $\mathrm{H} 2 \mathrm{O} 2)$-induced damage in vitro and in vivo tests. The free radical scavenging activities were tested on monkey kidney fibroblasts (Vero cells) and on zebrafish embryos. Both in vivo and in vitro tests demonstrated the potential of polysaccharides extracted from Codium fragile as neurorepair in animals [149] (Table 5).

Table 5. Preclinical studies on cell lines performed with seaweed bioactive compounds.

\begin{tabular}{|c|c|c|c|c|}
\hline Preclinical Trial & Cell Lines Surveyed & Dosage $(\mu \mathrm{g} / \mathrm{mL})$ & Effect & Reference \\
\hline $\begin{array}{l}\text { Antitumoral activity of } \\
\text { carregaagenans and } \\
\text { oligosaccharide fractions of } \\
\text { carregaagenans from } \\
\text { Kappaphycus striatum }\end{array}$ & $\begin{array}{l}\text { Human nasopharyngeal } \\
\text { carcinoma (KB), human gastric } \\
\text { carcinoma (BGC) and human } \\
\text { hela carcinoma (Hela) }\end{array}$ & $500,250,125$ & $\begin{array}{l}\text { The results of bioassay } \\
\text { showed that the fraction F1 } \\
\text { exhibits relatively higher } \\
\text { antitumor activity against } \\
\text { three cancer cells in vitro than } \\
\text { polysaccharides }\end{array}$ & [94] \\
\hline $\begin{array}{c}\text { Antitumoral activity of } \\
\text { ethanol:water extracts and } \\
\text { ethanol:chloroform extracts of } \\
\text { Laurencia papillosa }\end{array}$ & Jurkat cancer cells & $25-1000$ & $\begin{array}{l}\text { The number of the viable cells } \\
\text { is decreased with } \\
\text { ethanol:chloroform extract } \\
\text { with IC50 value of } \\
57.77 \mu \mathrm{g} / \mathrm{mL} \text { is (more } \\
\text { cytotoxic than the } \\
\text { ethanol:water extract with } \\
\text { IC50 value of } 121.642 \mu \mathrm{g} / \mathrm{mL} \text { ) }\end{array}$ & [99] \\
\hline
\end{tabular}

\footnotetext{
Antitumoral activity of three

sesquiterpenes (12-hydroxy isolaurene

8,11-dihydro-12-hydroxy isolaurene

and isolauraldehyde) obtained

from extract of the red alga Laurencia obtusa.
}

Ehrlich cells (Ehrlich ascites Carcinoma, EAC)
Isolauraldehyde proved to have the highest cytotoxic activity $(83.1 \%)$ followed by compound $2(79.9 \%)$ 
Table 5. Cont.

\begin{tabular}{|c|c|c|c|c|}
\hline Preclinical Trial & Cell Lines Surveyed & Dosage $(\mu \mathrm{g} / \mathrm{mL})$ & Effect & Reference \\
\hline $\begin{array}{l}\text { Antitumoral activity of ethanolic } \\
\text { extract of Gracilaria edulis }\end{array}$ & $\begin{array}{l}\text { Ehrlich ascites tumour (EAT) } \\
\text { cells from mice }\end{array}$ & $0-100$ & $\begin{array}{l}\text { EAT cells viability was close to } \\
65 \% \text { At } 50 \mu \mathrm{g} / \mathrm{mL} \text { dose and } \\
\text { the maximum decrease of } 15 \% \\
\text { was observed at } 100 \mu \mathrm{g} / \mathrm{mL}\end{array}$ & [97] \\
\hline $\begin{array}{l}\text { Antigenotoxicity activity of Ulva } \\
\text { rigida crude extracts on human } \\
\text { lymphocytes and protective } \\
\text { effects on chemotherapeutic } \\
\text { agent mitomycine-C. }\end{array}$ & In vitro human lymphocytes & $10,20,40$ & $\begin{array}{l}\text { Genotoxic activity in human } \\
\text { lymphocyte cell culture was } \\
\text { not high, while Ulva ridiga } \\
\text { extracts significantly } \\
\text { decreased the number of } \\
\text { chromosomal aberrations, the } \\
\text { frequencies of sister chromatid } \\
\text { exchange and micronuclei, } \\
\text { compared with the cell culture } \\
\text { treated with chemotherapeutic } \\
\text { agent mitomycine-C }\end{array}$ & [107] \\
\hline $\begin{array}{l}\text { Activation of LXR } \alpha \text { or } \mathrm{LXR} \beta \\
\text { (nuclear receptor) from } \\
\text { polysaccharide extracts of } \\
\text { Sargassum fusiforme }\end{array}$ & $\begin{array}{c}\text { Human microglia cells } \\
\text { (CHME3) from University } \\
\text { Paris-Sud, France and in vivo } \\
\text { from mice used as model of } \\
\text { survey for AD }\end{array}$ & $1,3,5$ & $\begin{array}{l}\text { In vitro CHME3 cells showed } \\
\text { a significantly activation of } \\
\text { LXR } \beta \text { but not LXR } \alpha \text { with dose } \\
\text { of } 5 \mu \mathrm{g} / \mathrm{mL} \text {. In vivo test } \\
\text { showed after ten weeks LXR } \\
\text { activation in the central } \\
\text { nervous system, evidenced by } \\
\text { a cerebral induction of LXR } \\
\text { response genes }\end{array}$ & [145] \\
\hline $\begin{array}{l}\text { Protection against A } \beta \text { - induced } \\
\text { neurotoxicity in PC } 12 \text { cells } \\
\text { trough isolated phlorotannins } \\
\text { from Eisenia bicyclis }\end{array}$ & $\begin{array}{l}\text { Rat pheochromocytoma cells } \\
\text { (PC12 cells) obtained from } \\
\text { American Type Culture } \\
\text { Collection (ATCC) }\end{array}$ & $2.5,5,10,20$ & $\begin{array}{l}\text { 7-phloroeckol and } \\
\text { phlorofucofuroeckol A have } \\
\text { been shown to be potent } \\
\text { neuroprotective agents }\end{array}$ & {$[147]$} \\
\hline $\begin{array}{l}\text { Protection against hydrogen } \\
\text { peroxide (H2O2)-induced } \\
\text { damage trough sulfated } \\
\text { polysaccharides from } \\
\text { Codium fragile }\end{array}$ & $\begin{array}{l}\text { Monkey kidney fibroblasts } \\
\text { (Vero cells) } \\
\text { Zebrafish embyos }\end{array}$ & $12.5,25,50$ & $\begin{array}{l}\text { In vivo and in vitro tests } \\
\text { showed the potential of } \\
\text { polysaccharides extracted as } \\
\text { neurorepair in animals }\end{array}$ & {$[149]$} \\
\hline
\end{tabular}

\subsection{Pharmaceutical Applications}

Seaweeds bioactive compounds are employed in pharmaceutical industry with the aim to contribute to new formulations for innovative drugs, in order to substitute synthetic compounds with natural ones. SPs from algae possess important pharmacological activities such as anticoagulant, antioxidant, antiproliferative, antitumoral, anti-inflammatory and antiviral activities [12,150,151] (Table 6).

Various SPs have been extracted from species from order Bryopsidales (Chlorophyta) and Dictyotales and Fucales (Phaeophyceae) showed anticoagulant activity similar to heparin due to the in vitro inhibition of factors $\mathrm{Xa}$ and IIa mediated by antithrombin and heparin cofactor II [30]. Both in vitro and in vivo experiments demonstrated that fucoidans extracted from Laminaria cichorioides (Phaeophyceae) [92] and Fucus evanescens [93] behave like heparin as well; thus, they show anticoagulant activity accelerating the development of antithrombin III to inhibit the effect against thrombin.

Moreover, the APTT test, which measures the Activated Partial Thromboplastin Clotting Time, has been performed with fucoidans extracted from Fucus vesiculosus and demonstrated that the clotting time was higher under the influence of these natural compounds in respect to the control. Additionally, the TT test (Thrombin Time), a blood test that measures the time it takes for a fibrin clot to form in the plasma of a blood sample, revealed a higher clotting time respect the control as well [152].

Fucoidans exert several properties. For example, Pozharitskaya et al. [152] evaluated the antioxidant, anti-inflammatory, anti-hyperglycaemic and anticoagulant bioactivities of high-molecular-weight fucoidans extracted from Fucus vesiculosus. These compounds showed free-radical scavenging activity, even thought was lower than synthetic antioxidants, but its activity is comparable to the natural antioxidant showed from the natural 
antioxidant quercetin, present in plants [152]. Moreover, the inhibitory activity has been shown on both isoforms of the pro-inflammatory cyclooxygenase (COX-1 and 2) enzymes, considering fucoidans extracted from Fucus vesiculosus promising compounds for antiinflammatory natural drugs [152]. Fucoidans from Fucus vesiculosus are also involved in the inhibition of the enzyme DPP-IV by fucoidan. This enzyme is related with the degradation of incretin hormones, which prevents higher amount of glucose in the blood (postprandial hyperglycemia); the new pharmaceutical is developing new DPP-IV inhibitors in order to decrease the glucose level in the blood and assure the anti-hyperglycaemic effect. Thus, the research of Pozharitskaya et al. [152] assesses that fucoidans may be involved in anti-hyperglycaemic activity trough the inhibition of DPP-IV.

Previous studies have reported that Sargassum fulvellum (Phaeophyceae) contains many bioactive molecules, such as phlorotannins, grasshopper ketone, fucoidan, and polysaccharides. Sargassum fulvellum extracts have been studied for years for analysing their diverse pharmacological effects such as antioxidant, anticancer, anti-inflammatory, antibacterial, and anticoagulant activities [153,154]. Extracts of Sargassum fulvellum were analysed to treat diseases such as a lumps, swelling, testicular pains, and urinary tract infections $[153,155,156]$.

Agar extracted from red algae is widely used in biomedicine as suspension component in drug solutions and in prescription products, but also as anticoagulant agents and as laxative in capsules [13]. Due to its biological and pharmacological properties, the red algae Gracilaria edulis is known all over the world. Extract of Gracilaria edulis showed diverse properties such as antidiabetic, antioxidant, antimicrobial, anticoagulant, anti-inflammatory, and antiproliferative activities [96]; thus, these compounds are apposable for new pharmaceutical formulations. Furthermore, Gunathilaka et al. [98], evaluated the in vitro hypoglycemic activity of phenolic, flavonoid and alkaloid extracts from Gracilaria edulis. The study revealed the hypoglycaemic potential of the red alga through the inhibition of carbohydrate-digesting enzymes, glucose absorption, and the formation of antiglycation end products. Ulva rigida (Chlorophyta) has been reported hypoglycemic effect in vivo as well [108].

The antiviral properties of seaweeds make them another valuable choice to ameliorate the health of infected people; moreover, their application in pharmaceutical will ensure new and natural antiviral agents, which can substitute synthetic compounds. Additionally, the implication of seaweeds' bioactive compounds is cost-efficient compared to the production of synthetic antivirals [157]. It has been discovered the protective effect of macroalgae antiviral activity against several viruses, such as human immune deficiency virus (HIV), Herpes Simplex Virus (HSV), genital warts [5], hepatitis C (HCV) [158]. Chlorophyta species have been proven effective against HSV [159,160], Encephalomyocarditis virus, Influenza "A" virus [161] or human metapneumovirus [110], to name a few. The antiviral action of macroalgae was first described by Gerber et al. [162] and it is associated with several compounds as fatty acids, diterpenes, but mainly with the presence of SPs $[2,150,162,163]$, which can inhibit replication of viruses or can contribute to improve the immune system to fight against the viral infection. The protein griffithsin found in red algae Griffithsia sp. (Rhodophyta) showed antiviral activity against MERS-CoV virus [100] and SARS-CoV glycoprotein [101]. It is likely that these compounds act against SARS-CoV2. Seaweeds' polysaccharides can contribute for the development of powerful antivirals, indeed polysaccharides extracted from Saccharina japonica (Phaeophyceae) demonstrate in vitro inhibition to SARS-CoV-2 [164]. 
Table 6. Pharmaceutical effects of seaweed bioactive compounds.

\begin{tabular}{|c|c|c|c|c|c|c|}
\hline Seaweed & $\begin{array}{l}\text { Compound } \\
\text { Extracted }\end{array}$ & $\begin{array}{l}\text { Cell Lines/Animals } \\
\text { Surveyed }\end{array}$ & $\begin{array}{c}\text { Route of } \\
\text { Administration }\end{array}$ & Dosage $(\mu \mathrm{g} / \mathrm{mL})$ & Effect & Reference \\
\hline $\begin{array}{c}\text { Laminaria } \\
\text { cichorioides } \\
\text { (Phaeophyceae) }\end{array}$ & Sulphated fucan & Human plasma & $\begin{array}{l}\text { The lyophilized } \\
\text { crude } \\
\text { polysaccharide } \\
\text { was dissolved in } \\
\text { human plasma }\end{array}$ & $10,30,50$ & $\begin{array}{c}\text { In vitro } \\
\text { anticoagulant } \\
\text { activity }\end{array}$ & [92] \\
\hline $\begin{array}{l}\text { Fucus evanescens } \\
\text { (Phaeophyceae) }\end{array}$ & Fucoidans & $\begin{array}{l}\text { Human plasma } \\
\text { Rat plasma }\end{array}$ & $\begin{array}{l}\text { Intravenous } \\
\text { Injection }\end{array}$ & $125,250,500,1000$ & $\begin{array}{l}\text { In vitro and } \\
\text { in vivo } \\
\text { anticoagulant } \\
\text { activity }\end{array}$ & [93] \\
\hline $\begin{array}{c}\text { Sargassum } \\
\text { fulvellum } \\
\text { (Phaeophyceae) }\end{array}$ & $\begin{array}{l}\text { Phlorotannins, } \\
\text { grasshopper } \\
\text { ketone, fucoidan } \\
\text { and } \\
\text { polysaccharides }\end{array}$ & Mice & $\begin{array}{c}\text { Oral } \\
\text { administration }\end{array}$ & $\begin{array}{l}\text { Based on weight of } \\
\text { mice }\end{array}$ & $\begin{array}{l}\text { Antioxidant, } \\
\text { anticancer, anti- } \\
\text { inflammatory, } \\
\text { antibacterial, and } \\
\text { anticoagulant } \\
\text { activities }\end{array}$ & [153] \\
\hline $\begin{array}{l}\text { Gracilaria edulis } \\
\text { (Rhodophyceae) }\end{array}$ & $\begin{array}{c}\text { Phenolic, } \\
\text { Flavonoid and } \\
\text { Alkaloid } \\
\text { compounds }\end{array}$ & $\begin{array}{l}\text { Bovine serum } \\
\text { albumin (protein) }\end{array}$ & $\begin{array}{l}\text { The extracts were } \\
\text { tested on the } \\
\text { protein }\end{array}$ & $\begin{array}{c}20,40,60,80,100 \\
120\end{array}$ & $\begin{array}{l}\text { Hypoglycaemic } \\
\text { activity }\end{array}$ & [98] \\
\hline $\begin{array}{c}\text { Ulva rigida } \\
\text { (Chlorophyceae) }\end{array}$ & Ethanolic extract & $\begin{array}{l}\text { Twenty-four male } \\
\text { Wistar rats }\end{array}$ & $\begin{array}{c}\text { Oral } \\
\text { administration }\end{array}$ & $\begin{array}{l}500 \mathrm{~mL} \text { of water } \\
\text { with extracts in } 2 \% \\
\text { wt/vol as drinking } \\
\text { water for exposed } \\
\text { groups per each day } \\
\text { (from } 3 \text { to } 30 \text { days). }\end{array}$ & $\begin{array}{c}\text { In vivo anti- } \\
\text { hyperglycaemic, } \\
\text { antioxidative and } \\
\text { geno- } \\
\text { toxic/antigenotoxic } \\
\text { activities }\end{array}$ & [108] \\
\hline $\begin{array}{c}\text { Griffithsia sp. } \\
\text { (Rhodophyceae) }\end{array}$ & $\begin{array}{l}\text { Griffithsin } \\
\text { (protein) }\end{array}$ & $\begin{array}{l}\text { MERS-CoV and } \\
\text { SARS-CoV } \\
\text { glycoproteins }\end{array}$ & $\begin{array}{l}\text { The extracts were } \\
\text { tested on the } \\
\text { proteins }\end{array}$ & $0.125,0.25,0.5,1,2$ & $\begin{array}{l}\text { Antiviral activity } \\
\text { against } \\
\text { MERS-CoV virus } \\
\text { and SARS-CoV } \\
\text { glycoprotein }\end{array}$ & [100] \\
\hline $\begin{array}{l}\text { Saccharina japonica } \\
\text { (Phaeophyceae) }\end{array}$ & polysaccharides & SARS-CoV-2 S-protein & $\begin{array}{l}\text { The extracts were } \\
\text { tested on the } \\
\text { protein }\end{array}$ & $50-500$ & $\begin{array}{l}\text { In vitro inhibition } \\
\text { to SARS-CoV-2 }\end{array}$ & [164] \\
\hline
\end{tabular}

Even though the development of new antiviral formulations to cure viral infections is a real possibility [165], it is necessary to implement the evaluation and research of algal bio-compounds: only through the screen of high number of bioactive compounds might be possible to develop new natural drugs.

\subsection{Cosmetics}

Extracts of vitamins, minerals, amino acids, sugars, lipids and other biologically active compounds of several species of red and brown seaweeds are involved in cosmetic industry [166]. For instance, Macrocystis pyrifera (Phaeophyceae) commonly known as giant kelp, possesses phycocolloids that are used as a thickening agent in cosmetics by other industries [167].

Phloroeckol and tetrameric phloroglucinol (phlorotannins) from Macrocystis pyrifera revealed to exhibit antioxidant activity, which can contribute to prevent skin aging [90], thus protecting the skin from exposure to UV radiation and delaying the natural physiological changes; it also provides the consumer with a better quality of life and improves selfesteem [168].

Extracts of Fucus vesiculosus (Phaeophyceae) have been used to reduce the appearance of "eye bags" and the dark circles on the skin area under the eyes. The anti-inflammatory and antioxidant properties of the extracts stimulate the expression of haem oxygenase-1 (HO-l), a molecule that eliminates the haem production on the skin by removing haem catabolites. Furthermore, this extract stimulates collagen production that could help to 
reduce fine lines and wrinkles. In addition, it could diminish or even avoid skin aging by using make-up and sunscreens [91].

Rhodophyta bioactive compounds are widely used in cosmetics, especially iotacarrageenan and $\mathrm{k}$-carrageenan which are available in products in the market. Creams, lotions, toothpaste, hair tonics, soaps, sunscreens, etc., are frequently enriched with carrageenan [169].

Bioactive compounds from Chlorophyta are also included in cosmetic industry. The antioxidant activity of the polysaccharide ulvan is attractive for novel and natural cosmetic formulations, since it was demonstrated, in vitro, the protective capability against hydrogen peroxide-induced oxidative stress. Furthermore, the presence of glucuronic acid adds moisturizing properties, and the rhamnosyl residues assure cell proliferation and collagen synthesis capacities, confirming ulvan as interesting raw material for the cosmetic industries [170].

\section{Seaweeds Extracts in Industrial Applications}

Seaweeds biological compounds are widely exploited in several industrial applications (Table 4). For example, these compounds have been explored for the production of biogas and biodiesel, which can be an alternative and efficient fuel to replace the use of fossil fuels. The SP ulvan extracted from the green seaweed possesses attractive physicochemical properties and biological activities, resulting in its applications in different innovative applications [171,172].

Ulvan extracted from Ulva lactuca (Chlorophyta) has been tested for production of biogas [104] and biodiesel [105]. Moreover, the optical, structural, thermal, and antioxidant properties make ulvan a potential contribute for new packaging material for food [173]. Ulvan from Ulva fasciata (Chlorophyta) was extracted and utilized to create edible films for food application. The films presented good mechanical and physicochemical properties adapted for containing food. The water vapour permeability in the pack decreased, preserving better the food. Moreover, ulvan from Ulva fasciata presents strong antioxidant activity [109], making this polysaccharide a perfect candidate for the production of novel, sustainable and eco-friendly bioplastics.

\subsection{Agriculture}

Seaweeds are utilized as compost to improve soil fertility and ameliorate plants cultivations [15-17]. The use of seaweeds as organic fertilizer in agriculture compensates the deficiency of plant nutrients such as nitrogen, phosphorous and potassium [174].

However, to avoid excess of salt, sand, and heavy metal content into the soil by using the whole seaweed [175], extracts of seaweeds have been considered for production of fertilizers $[16,176,177]$. Many countries already utilized seaweeds extracts to produce new formulations for fertilizers in agriculture $[15,178]$ because of their advantages which are: stimulation of seed germination, improved crop performance and yield, increased resistance to abiotic and biotic stress such as phytopathogenic fungi [179], bacteria [180], insects [181] and enhanced postharvest life and quality of the product [16,182]. Moreover, the use of seaweed is a solution to overcome hazards caused by the extensive use of chemical fertilizers. Chemical fertilizers can give us health issues, while seaweed derived fertilizers are biodegradable, non-toxic, non-polluting and non-hazardous to human beings, animals and birds [183].

It is well known that macro and microminerals are essential to soil fertility and plant development; thus, the involved in seaweeds rich in minerals and nutrients could be a sustainable solution. The brown algae Saccharina japonica contains $\mathrm{Ca}, \mathrm{Mg}, \mathrm{P}, \mathrm{K}$, and $\mathrm{Na}$ as the main macrominerals, and $\mathrm{Fe}, \mathrm{I}, \mathrm{Mn}, \mathrm{Zn}$, and $\mathrm{Al}$ as the principal microminerals [184], therefore its extracts can contribute for the formulation of new biofertilizers. The European algae Saccorhiza polyschides (Phaeophyceae) has been evaluated from Soares et al. [174]. The study demonstrated that its minerals and essential trace elements were present in high quantity, suggesting Saccorhiza polyschides an interesting candidate for biofertilizer. 
In recent years, the consideration for spray fertilizers based on seaweed increases, and they are extensively used in agriculture and horticulture [185]. Seaweed liquid fertilizer of extract of Codium decorticatum (Chlorophyta) has been tested to improve the growth of chilly plants. The effect of $\mathrm{N}, \mathrm{Mg}, \mathrm{K}$ and some trace elements contained in the extracts were positive for the crop plants. Extracts of Codium decorticatum were also used as biostimulants of tomato seed germination and plant growth. It was found that the compounds in the extract from green seaweeds increased seed germination percentage, plant biomass, and the content of chlorophylls a and b [186]. Thus, the liquid fertilizer from Codium decorticatum might be a solid and low-cost biofertilizer [187].

Considering the new approach of the agricultural industry, where the search of new sustainable and eco-friendly products is increasing, the role of seaweeds is extremely important. The utilization of natural fertilizers assures soils conditioned by natural antifungal agents [188] and healthy crops. Therefore, the involvement of seaweeds in agriculture will contribute also for human health welfare.

\subsection{Animal Feed}

The addition of seaweeds extracts in feed products will reduce the use of synthetic substances, which can provoke health issues. The demand for natural food or natural supplement food is growing. Unfortunately, the food safety regulatory framework is not fully harmonized between the countries, creating a problem in feed safety chain, increasing the animal health risks; consequently, human health is at risk when consuming animal meat [189]. Thus, the inclusion of seaweeds in animal diets will improve the quality of food and ensure sustainable and safe products.

Seaweeds are already used to enrich animal diets, for example, extracts obtained from Ascophyllum nodosum (Phaeophyceae) in Norway and the UK, Laminaria digitata (Phaeophyceae) in France, Ascophyllum and Laminaria species in Iceland already provide the main commercial ingredients used to feed land animals [190]. Ascophyllum nodosum extracts can be promising additive to increase food safety. These extracts have been mixed at $2 \%$ in meal for cattle and lambs during the 2 last weeks before slaughter. A reduction in Escherichia coli O157:H7 has been reported [191-193], possibly due to the presence of phlorotannins [194]. Reduction in other pathogenic microorganism such as Salmonella sp., Campylobacter species and Clostridia in the gastrointestinal track of domestic animals has also been observed [195].

The use of seaweed might be a solution of uptake of iodine in cases of iodine deficiency intake. Ascophyllum nodosum has been used to feed pigs in Belgium, by integrating $2 \%$ dried seaweed (the seaweed-based diet contained $10 \mathrm{mg} / \mathrm{kg}$ of iodine $\mathrm{vs} .1 \mathrm{mg} / \mathrm{kg}$ for the control diet) into pig feed. The iodine concentration increases from 2.7 to 6.8 , in different tissues. This feeding strategy for producing iodine-enriched meat was found to be a good solution to human iodine supply, without risk for overdosing or the need for a shift in eating pattern [196].

Additionally, seaweed extracts utilized as supplement to fish diets enhance the growth, lipid metabolism, physiological activity, stress response, disease resistance and carcass quality of various fish species [197-199]. For example, Saccharina latissima (Phaeophyceae) demonstrated potential as feed additive: its bioactive compounds ameliorate fish farming, and also increase protective activity against oxidative stress in fish [200].

\section{Conclusions}

Marine seaweeds are a great food source with bioactive components that promote a healthy diet with the advantage to exhibit anticancer, antiviral, antifungal, antidiabetic, antihypertensive, immunomodulatory, anticoagulant, anti-inflammatory, antioxidant, UVprotective, and neuroprotective properties after assimilation. Their low amount of fat makes them a key food in dietary. Brown seaweeds are among the most exploited, with red algae, widely used in food, nutraceutical, pharmaceutical and cosmetic industry. Unfortunately, not all seaweeds follow the criteria to be considered as food within safety standards. 
Seaweeds tend to accumulate heavy metals and minerals, which could deteriorate animal and human health if consumed in food or drugs.

The use of seaweeds bioactive compounds in biotechnological and industrial applications will promote a healthier lifestyle in a sustainable way. Thus, it is important to sustain and go further on the research of bioactive compounds of seaweeds in order to recognize and neutralize the effect of potentially harmful compounds, and increase the application of seaweeds' compounds. The use of seaweeds bioactive compounds in biotechnological and industrial applications will promote a human well-being by contributing for the usage of natural products instead of chemicals.

Author Contributions: Conception and design of the idea: S.L. and A.M.M.G.; writing and bibliographic research: S.L. and A.M.M.G.; supervision and manuscript revision: J.C.M. and A.M.M.G. All authors have read and agreed to the published version of the manuscript.

Funding: This work is financed by national funds through FCT-Foundation for Science and Technology, I.P., within the scope of the projects UIDB/04292/2020—granted to MARE-Marine and Environmental Sciences Centre and UIDP/50017/2020+UIDB/50017/2020 (by FCT/MTCES) granted to CESAM - Centre for Environmental and Marine Studies. This research was co-financed by the project MENU—Marine Macroalgae: Alternative recipes for a daily nutritional diet (FA_05_2017_011), funded by the Blue Fund under Public Notice No. 5-Blue Biotechnology. Silvia Lomartire thanks to the project PORBIOTA, E-Infrastructure Portuguese Information and Research in Biodiversity (POCI-01-0145-FEDER-022127), which co-financed this research supported by Competitiveness and Internationalization Operational Programme and Regional Operational Programme of Lisbon, through FEDER, and by the Portuguese Foundation for Science and Technology (FCT), through national funds (OE). Ana M. M. Gonçalves acknowledges University of Coimbra for the contract IT057-18-7253.

Institutional Review Board Statement: Not applicable.

Data Availability Statement: Not applicable.

Conflicts of Interest: The authors declare no conflict of interest.

\section{References}

1. Dhargalkar, V. Uses of seaweeds in the Indian diet for sustenance and well-being. Sci. Cult. 2015, 80, 192-202.

2. Pereira, L. Therapeutic and Nutritional Uses of Algae; CRC Press/Taylor \& Francis Group: Boca Raton, FL, USA, 2018.

3. Rajapakse, N.; Kim, S.K. Nutritional and Digestive Health Benefits of Seaweed, 1st ed.; Elsevier Inc.: Amsterdam, The Netherlands, 2011; Volume 64, ISBN 9780123876690.

4. Shannon, E.; Abu-Ghannam, N. Seaweeds as nutraceuticals for health and nutrition. Phycologia 2019, 58, 563-577. [CrossRef]

5. Panzella, L.; Napolitano, A. Natural phenol polymers: Recent advances in food and health applications. Antioxidants 2017, 6, 30. [CrossRef] [PubMed]

6. Salehi, B.; Sharifi-Rad, J.; Seca, A.M.; Pinto, D.C.; Michalak, I.; Trincone, A.; Mishra, N.; Nigam, M.; Zam, W. Martins Current Trends on Seaweeds: Looking at Chemical Composition, Phytopharmacology, and Cosmetic Applications. Molecules 2019, 24, 4182. [CrossRef] [PubMed]

7. Khotimchenko, M.; Tiasto, V.; Kalitnik, A.; Begun, M.; Khotimchenko, R.; Leonteva, E.; Bryukhovetskiy, I.; Khotimchenko, Y. Antitumor potential of carrageenans from marine red algae. Carbohydr. Polym. 2020, 246, 116568. [CrossRef]

8. Pádua, D.; Rocha, E.; Gargiulo, D.; Ramos, A.A. Bioactive compounds from brown seaweeds: Phloroglucinol, fucoxanthin and fucoidan as promising therapeutic agents against breast cancer. Phytochem. Lett. 2015, 14, 91-98. [CrossRef]

9. Percival, E. The polysaccharides of green, red and brown seaweeds: Their basic structure, biosynthesis and function. Br. Phycol. J. 1979, 14, 103-117. [CrossRef]

10. Hirmo, S.; Utt, M.; Ringner, M.; Wadström, T. Inhibition of heparan sulphate and other glycosaminoglycans binding to Helicobacter pylori by various polysulphated carbohydrates. FEMS Immunol. Med. Microbiol. 1995, 10, 301-306. [CrossRef]

11. Adhikari, U.; Mateu, C.G.; Chattopadhyay, K.; Pujol, C.A.; Damonte, E.B.; Ray, B. Structure and antiviral activity of sulfated fucans from Stoechospermum marginatum. Phytochemistry 2006, 67, 2474-2482. [CrossRef]

12. Cumashi, A.; Ushakova, N.A.; Preobrazhenskaya, M.E.; D’Incecco, A.; Piccoli, A.; Totani, L.; Tinari, N.; Morozevich, G.E.; Berman, A.E.; Bilan, M.I.; et al. A comparative study of the anti-inflammatory, anticoagulant, antiangiogenic, and antiadhesive activities of nine different fucoidans from brown seaweeds. Glycobiology 2007, 17, 541-552. [CrossRef]

13. Pal, A.; Kamthania, M.C.; Kumar, A. Bioactive Compounds and Properties of Seaweeds-A Review. OALib 2014, 01, 1-17. [CrossRef] 
14. Bajpai, V.K.; Rather, I.A.; Lim, J.; Park, Y.H. Diversity of bioactive polysaccharide originated from marine sources: A review. Indian J. Geo-Marine Sci. 2014, 43, 1857-1869.

15. Nabti, E.; Jha, B.; Hartmann, A. Impact of seaweeds on agricultural crop production as biofertilizer. Int. J. Environ. Sci. Technol. 2017, 14, 1119-1134. [CrossRef]

16. Craigie, J.S. Seaweed extract stimuli in plant science and agriculture. J. Appl. Phycol. 2011, 23, 371-393. [CrossRef]

17. Illera-Vives, M.; Seoane Labandeira, S.; Iglesias Loureiro, L.; López-Mosquera, M.E. Agronomic assessment of a compost consisting of seaweed and fish waste as an organic fertilizer for organic potato crops. J. Appl. Phycol. 2017, 29, 1663-1671. [CrossRef]

18. Plaza, M.; Herrero, M.; Alejandro Cifuentes, A.; Ibáñez, E. Innovative natural functional ingredients from microalgae. J. Agric. Food Chem. 2009, 57, 7159-7170. [CrossRef] [PubMed]

19. Torres, M.D.; Flórez-Fernández, N.; Domínguez, H. Integral utilization of red seaweed for bioactive production. Mar. Drugs 2019, 17. [CrossRef]

20. Chandini, S.K.; Ganesan, P.; Bhaskar, N. In vitro antioxidant activities of three selected brown seaweeds of India. Food Chem. 2008, 107, 707-713. [CrossRef]

21. Knowler, D.; Chopin, T.; Martínez-Espiñeira, R.; Neori, A.; Nobre, A.; Noce, A.; Reid, G. The economics of Integrated Multi-Trophic Aquaculture: Where are we now and where do we need to go? Rev. Aquac. 2020, raq.12399. [CrossRef]

22. Pangestuti, R.; Kim, S.K. Neuroprotective effects of marine algae. Mar. Drugs 2011, 9, 803-818. [CrossRef]

23. Yan, X.; Chuda, Y.; Suzuki, M.; Nagata, T. Fucoxanthin as the major antioxidant in Hijikia fusiformis, a common edible seaweed. Biosci. Biotechnol. Biochem. 1999, 63, 605-607. [CrossRef]

24. Maeda, H.; Hosokawa, M.; Sashima, T.; Funayama, K.; Miyashita, K. Fucoxanthin from edible seaweed, Undaria pinnatifida, shows antiobesity effect through UCP1 expression in white adipose tissues. Biochem. Biophys. Res. Commun. 2005, 332, 392-397. [CrossRef]

25. Pigmen, K.; Yip, W.H.; Lim, S.J.; Mustapha, W.A.W.; Maskat, M.Y.; Said, M.; Pigmen, K. Characterisation and Stability of Pigments Extracted from Sargassum binderi Obtained from Semporna, Sabah. Sains Malaysiana 2014, 43, 1345-1354.

26. Zvyagintseva, T.N.; Shevchenko, N.M.; Popivnich, I.B.; Isakov, V.V.; Scobun, A.S.; Sundukova, E.V.; Elyakova, L.A. A new procedure for the separation of water-soluble polysaccharides from brown seaweeds. Carbohydr. Res. 1999, 322, 32-39. [CrossRef]

27. Honya, M.; Mori, H.; Anzai, M.; Araki, Y.; Nisizawa, K. Monthly Changes in the Content of Fucans, Their Constituent Sugars and Sulphate in Cultured Laminaria japonica; Developments in Hydrobiology Book Series; Springer: Dordrecht, The Netherland, 1999; Volume 398, pp. 411-416.

28. Zvyagintseva, T.N.; Shevchenko, N.M.; Chizhov, A.O.; Krupnova, T.N.; Sundukova, E.V.; Isakov, V.V. Water-soluble polysaccharides of some far-eastern brown seaweeds. Distribution, structure, and their dependence on the developmental conditions. J. Exp. Mar. Bio. Ecol. 2003, 294, 1-13. [CrossRef]

29. Fitton, J.; Stringer, D.; Karpiniec, S. Therapies from Fucoidan: An Update. Mar. Drugs 2015, 13, 5920-5946. [CrossRef] [PubMed]

30. Li, B.; Lu, F.; Wei, X.; Zhao, R. Fucoidan: Structure and bioactivity. Molecules 2008, 13, 1671-1695. [CrossRef]

31. Vishchuk, O.S.; Ermakova, S.P.; Zvyagintseva, T.N. The fucoidans from brown algae of Far-Eastern seas: Anti-tumor activity and structure-function relationship. Food Chem. 2013, 141, 1211-1217. [CrossRef]

32. Fitton, J.H. Therapies from fucoidan; multifunctional marine polymers. Mar. Drugs 2011, 9, 1731-1760. [CrossRef] [PubMed]

33. Bilan, M.I.; Grachev, A.A.; Ustuzhanina, N.E.; Shashkov, A.S.; Nifantiev, N.E.; Usov, A.I. Structure of a fucoidan from the brown seaweed Fucus evanescens C.Ag. Carbohydr. Res. 2002, 337, 719-730. [CrossRef]

34. Bilan, M.I.; Grachev, A.A.; Ustuzhanina, N.E.; Shashkov, A.S.; Nifantiev, N.E.; Usov, A.I. A highly regular fraction of a fucoidan from the brown seaweed Fucus distichus L. Carbohydr. Res. 2004, 339, 511-517. [CrossRef] [PubMed]

35. Chizhov, A.O.; Dell, A.; Morris, H.R.; Haslam, S.M.; McDowell, R.A.; Shashkov, A.S.; Nifant'ev, N.E.; Khatuntseva, E.A.; Usov, A.I. A study of fucoidan from the brown seaweed Chorda filum. Carbohydr. Res. 1999, 320, 108-119. [CrossRef]

36. Szekalska, M.; Puciłowska, A.; Szymańska, E.; Ciosek, P.; Winnicka, K. Alginate: Current Use and Future Perspectives in Pharmaceutical and Biomedical Applications. Int. J. Polym. Sci. 2016, 2016, 1-17. [CrossRef]

37. Enquist-Newman, M.; Faust, A.M.E.; Bravo, D.D.; Santos, C.N.S.; Raisner, R.M.; Hanel, A.; Sarvabhowman, P.; Le, C.; Regitsky, D.D.; Cooper, S.R.; et al. Efficient ethanol production from brown macroalgae sugars by a synthetic yeast platform. Nature 2014, 505, 239-243. [CrossRef]

38. Benavides, S.; Villalobos-Carvajal, R.; Reyes, J.E. Physical, mechanical and antibacterial properties of alginate film: Effect of the crosslinking degree and oregano essential oil concentration. J. Food Eng. 2012, 110, 232-239. [CrossRef]

39. Sreekumar, K. Alginic Acid: A Potential Biopolymer from Brown Algae. Mater. Int. 2020, 2, 433-438.

40. Zemke-White, W.; Lindsey Ohno, M. World seaweed utilisation: An end-of-century summary W. J. Appl. Phycol. 1999, 125, 369-376. [CrossRef]

41. Nelson, T.E.; Lewis, B.A. Separation and characterization of the soluble and insoluble components of insoluble laminaran. Carbohydr. Res. 1974, 33, 63-74. [CrossRef]

42. Rioux, L.E.; Turgeon, S.L.; Beaulieu, M. Characterization of polysaccharides extracted from brown seaweeds. Carbohydr. Polym. 2007, 69, 530-537. [CrossRef]

43. Li, X.; Fan, X.; Han, L.; Lou, Q. Fatty acids of some algae from the Bohai Sea. Phytochemistry 2002, 59, 157-161. [CrossRef] 
44. Narayan, B.; Miyashita, K.; Hosokawa, M. Comparative Evaluation of Fatty Acid Composition of Different Sargassum (Fucales, Phaeophyta) Species Harvested from Temperate and Tropical Waters. J. Aquat. Food Prod. Technol. 2004, 13, 53-70. [CrossRef]

45. Kamenarska, Z.G.; Dimitrova-Konaklieva, S.D.; Stefanov, K.L.; Popov, S.S. A comparative study on the sterol composition of some brown algae from the Black Sea. J. Serbian Chem. Soc. 2003, 68, 269-275. [CrossRef]

46. Patterson, G.W. The distribution of sterols in algae. Lipids 1971, 6, 120-127. [CrossRef]

47. Fattorusso, E.; Magno, S.; Mayol, L. Sterols of mediterranean chlorophyceae. Experientia 1980, 36, 1137-1138. [CrossRef]

48. Kang, M.C.; Cha, S.H.; Wijesinghe, W.A.J.P.; Kang, S.M.; Lee, S.H.; Kim, E.A.; Song, C.B.; Jeon, Y.J. Protective effect of marine algae phlorotannins against AAPH-induced oxidative stress in zebrafish embryo. Food Chem. 2013, 138, 950-955. [CrossRef]

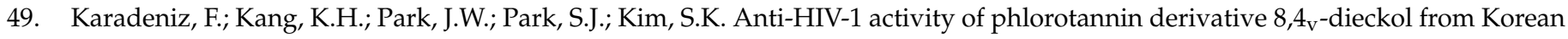
brown alga Ecklonia cava. Biosci. Biotechnol. Biochem. 2014, 78, 1151-1158. [CrossRef]

50. Ko, S.C.; Cha, S.H.; Heo, S.J.; Lee, S.H.; Kang, S.M.; Jeon, Y.J. Protective effect of Ecklonia cava on UVB-induced oxidative stress: In vitro and in vivo zebrafish model. J. Appl. Phycol. 2011, 23, 697-708. [CrossRef]

51. Arnold, T.M.; Targett, N.M. Quantifying in situ rates of phlorotannin synthesis and polymerization in marine brown algae. $J$. Chem. Ecol. 1998, 24, 577-595. [CrossRef]

52. Li, Y.-X.; Wijesekara, I.; Li, Y.; Kim, S.-K. Phlorotannins as bioactive agents from brown algae. Process Biochem. 2011, 46, 2219-2224. [CrossRef]

53. Ahn, M.J.; Yoon, K.D.; Min, S.Y.; Lee, J.S.; Kim, J.H.; Kim, T.G.; Kim, S.H.; Kim, N.G.; Huh, H.; Kim, J. Inhibition of HIV-1 reverse transcriptase and protease by phlorotannins from the brown alga Ecklonia cava. Biol. Pharm. Bull. 2004. [CrossRef] [PubMed]

54. Zou, Y.; Qian, Z.J.; Li, Y.; Kim, M.M.; Lee, S.H.; Kim, S.K. Antioxidant effects of phlorotannins isolated from Ishige okamurae in free radical mediated oxidative systems. J. Agric. Food Chem. 2008, 56, 7001-7009. [CrossRef]

55. O'Sullivan, A.M.; O'Callaghan, Y.C.; O'Grady, M.N.; Queguineur, B.; Hanniffy, D.; Troy, D.J.; Kerry, J.P.; O’Brien, N.M. In vitro and cellular antioxidant activities of seaweed extracts prepared from five brown seaweeds harvested in spring from the west coast of Ireland. Food Chem. 2011, 126, 1064-1070. [CrossRef]

56. Lee, J.W.; Seok, J.K.; Boo, Y.C. Ecklonia cava Extract and Dieckol Attenuate Cellular Lipid Peroxidation in Keratinocytes Exposed to PM10. Evidence-based Complement. Altern. Med. 2018, 2018. [CrossRef] [PubMed]

57. Turck, D.; Bresson, J.; Burlingame, B.; Dean, T.; Fairweather-Tait, S.; Heinonen, M.; Hirsch-Ernst, K.I.; Mangelsdorf, I.; McArdle, H.J.; Naska, A.; et al. Safety of Ecklonia cava phlorotannins as a novel food pursuant to Regulation (EC) No 258/97. EFSA J. 2017, 15. [CrossRef]

58. Catarino, M.D.; Silva, A.M.S.; Mateus, N.; Cardoso, S.M. Optimization of phlorotannins extraction from Fucus vesiculosus and evaluation of their potential to prevent metabolic disorders. Mar. Drugs 2019, 17. [CrossRef]

59. Heo, S.J.; Ko, S.C.; Cha, S.H.; Kang, D.H.; Park, H.S.; Choi, Y.U.; Kim, D.; Jung, W.K.; Jeon, Y.J. Effect of phlorotannins isolated from Ecklonia cava on melanogenesis and their protective effect against photo-oxidative stress induced by UV-B radiation. Toxicol. Vitr. 2009, 23, 1123-1130. [CrossRef]

60. Wijesinghe, W.A.J.P.; Ko, S.C.; Jeon, Y.J. Effect of phlorotannins isolated from Ecklonia cava on angiotensin I-converting enzyme (ACE) inhibitory activity. Nutr. Res. Pract. 2011, 5, 93-100. [CrossRef]

61. Eom, S.H.; Kim, Y.M.; Kim, S.K. Antimicrobial effect of phlorotannins from marine brown algae. Food Chem. Toxicol. 2012, 50, 3251-3255. [CrossRef]

62. Sugiura, Y.; Matsuda, K.; Yamada, Y.; Nishikawa, M.; Shioya, K.; Katsuzaki, H.; Imai, K.; Amano, H. Isolation of a new anti-allergic phlorotannin, phlorofucofuroeckol-B, from an edible brown alga, Eisenia arborea. Biosci. Biotechnol. Biochem. 2006, 70, $2807-2811$. [CrossRef] [PubMed]

63. Vieira, A.P.; Stein, E.M.; Andreguetti, D.X.; Colepicolo, P.; Ferreira, A.M.D.C. Preparation of silver nanoparticles using aqueous extracts of the red algae Laurencia aldingensis and Laurenciella sp. And their cytotoxic activities. J. Appl. Phycol. 2016, 28, 2615-2622. [CrossRef]

64. Kladi, M.; Xenaki, H.; Vagias, C.; Papazafiri, P.; Roussis, V. New cytotoxic sesquiterpenes from the red algae Laurencia obtusa and Laurencia microcladia. Tetrahedron 2006, 62, 182-189. [CrossRef]

65. Cosenza, V.A.; Navarro, D.A.; Pujol, C.A.; Damonte, E.B.; Stortz, C.A. Partial and total C-6 oxidation of gelling carrageenans. Modulation of the antiviral activity with the anionic character. Carbohydr. Polym. 2015, 128, 199-206. [CrossRef] [PubMed]

66. dos Santos-Fidencio, G.C.; Gonçalves, A.G.; Noseda, M.D.; Duarte, M.E.R.; Ducatti, D.R.B. Effects of carboxyl group on the anticoagulant activity of oxidized carrageenans. Carbohydr. Polym. 2019, 214, 286-293. [CrossRef] [PubMed]

67. McKim, J.M.; Willoughby, J.A.; Blakemore, W.R.; Weiner, M.L. Clarifying the confusion between poligeenan, degraded carrageenan, and carrageenan: A review of the chemistry, nomenclature, and in vivo toxicology by the oral route. Crit. Rev. Food Sci. Nutr. 2019, 59, 3054-3073. [CrossRef]

68. Vera, J.; Castro, J.; Gonzalez, A.; Moenne, A. Seaweed polysaccharides and derived oligosaccharides stimulate defense responses and protection against pathogens in plants. Mar. Drugs 2011, 9, 2514-2525. [CrossRef] [PubMed]

69. Lee, W.K.; Lim, Y.Y.; Leow, A.T.C.; Namasivayam, P.; Ong Abdullah, J.; Ho, C.L. Biosynthesis of agar in red seaweeds: A review. Carbohydr. Polym. 2017, 164, 23-30. [CrossRef]

70. Ramawat, K.G.; Merillon, J.M. Polysaccharides: Bioactivity and Biotechnology; Springer International Publishing: Cham, Switzerland, 2015.

71. Marinho-Soriano, E.; Bourret, E. Polysaccharides from the red seaweed Gracilaria dura (Gracilariales, Rhodophyta). Bioresour. Technol. 2005, 96, 379-382. [CrossRef] 
72. Lahaye, M.; Rochas, C. Chemical structure and physico-chemical properties of agar. Int. Work. Gelidium 1991, 137-148. [CrossRef]

73. Bixler, H.J.; Porse, H. A decade of change in the seaweed hydrocolloids industry. J. Appl. Phycol. 2011, 23, 321-335. [CrossRef]

74. Murano, E.; Toffanin, R.; Pedersini, C.; Carabot-Cuervo, A.; Blunden, G.; Rizzo, R. Structure and properties of agar from two unexploited agarophytes from Venezuela. Hydrobiologia 1996, 326-327, 497-500. [CrossRef]

75. Santelices, B.; Westermeier, R.; Bobadilla, M. Effects of stock loading and planting distance on the growth and production of Gracilaria chilensis in rope culture. J. Appl. Phycol. 1993, 5, 517-524. [CrossRef]

76. Cordover, R. Seaweed Agronomy; Rural Industries Research and Development Corporation (RIRDC): Wagga Wagga, Australia, 2007.

77. Kadam, S.U.; Tiwari, B.K.; O’Donnell, C.P. Application of novel extraction technologies for bioactives from marine algae. J. Agric. Food Chem. 2013, 61, 4667-4675. [CrossRef] [PubMed]

78. Khotimchenko, S.V. Fatty acids of green macrophytic algae from the sea of Japan. Phytochemistry 1993, 32, 1203-1207. [CrossRef]

79. Thompson, G.A. Lipids and membrane function in green algae. Biochim. Biophys. Acta 1996, 1302, 17-45. [CrossRef]

80. Khotimchenko, S.V.; Vaskovsky, V.E.; Titlyanova, T.V. Fatty acids of marine algae from the pacific coast of North California. Bot. Mar. 2002, 45, 17-22. [CrossRef]

81. Lahaye, M.; Robic, A. Structure and function properties of Ulvan, a polysaccharide from green seaweeds. Biomacromolecules 2007, 8, 1765-1774. [CrossRef] [PubMed]

82. Khan, M.N.A.; Choi, J.S.; Lee, C.M.; Kim, E.; Nam, T.J.; Fujii, H.; Hong, Y.K. Anti-inflammatory activities of methanol extracts from various seaweed species. J. Environ. Biol. 2008, 29, 465-469.

83. Wang, R.; Paul, V.J.; Luesch, H. Seaweed extracts and unsaturated fatty acid constituents from the green alga Ulva lactuca as activators of the cytoprotective Nrf2-ARE pathway. Free Radic. Biol. Med. 2013, 57, 141-153. [CrossRef]

84. Kapetanović, R.; Sladić, D.; Popov, S.; Zlatović, M.; Kljajić, Z.; Gašić, M.J. Sterol composition of the adriatic sea algae Ulva lactuca, Codium dichotomum, Cystoseira adriatica and Fucus virsoides. J. Serbian Chem. Soc. 2005, 70, 1395-1400. [CrossRef]

85. Sánchez-Machado, D.I.; López-Cervantes, J.; López-Hernández, J.; Paseiro-Losada, P. Fatty acids, total lipid, protein and ash contents of processed edible seaweeds. Food Chem. 2004, 85, 439-444. [CrossRef]

86. Jesumani, V.; Du, H.; Aslam, M.; Pei, P.; Huang, N. Potential use of seaweed bioactive compounds in skincare-A review. Mar. Drugs 2019, 17, 1-19. [CrossRef]

87. Robic, A.; Bertrand, D.; Sassi, J.F.; Lerat, Y.; Lahaye, M. Determination of the chemical composition of ulvan, a cell wall polysaccharide from Ulva spp. (Ulvales, Chlorophyta) by FT-IR and chemometrics. J. Appl. Phycol. 2009, 21, 451-456. [CrossRef]

88. Paradossi, G.; Cavalieri, F.; Pizzoferrato, L.; Liquori, A.M. A physico-chemical study on the polysaccharide ulvan from hot water extraction of the macroalga Ulva. Int. J. Biol. Macromol. 1999, 25, 309-315. [CrossRef]

89. Tziveleka, L.A.; Pippa, N.; Georgantea, P.; Ioannou, E.; Demetzos, C.; Roussis, V. Marine sulfated polysaccharides as versatile polyelectrolytes for the development of drug delivery nanoplatforms: Complexation of ulvan with lysozyme. Int. J. Biol. Macromol. 2018, 118, 69-75. [CrossRef] [PubMed]

90. Leyton, A.; Pezoa-Conte, R.; Barriga, A.; Buschmann, A.H.; Mäki-Arvela, P.; Mikkola, J.P.; Lienqueo, M.E. Identification and efficient extraction method of phlorotannins from the brown seaweed Macrocystis pyrifera using an orthogonal experimental design. Algal Res. 2016, 16, 201-208. [CrossRef]

91. Sun, Y.; Chavan, M. Comsetic Composition Comprising Marine Plants. US Patent US20140141035A1, 28 March 2017.

92. Yoon, S.J.; Pyun, Y.R.; Hwang, J.K.; Mourão, P.A.S. A sulfated fucan from the brown alga Laminaria cichorioides has mainly heparin cofactor II-dependent anticoagulant activity. Carbohydr. Res. 2007, 342, 2326-2330. [CrossRef]

93. Drozd, N.N.; Tolstenkov, A.S.; Makarov, V.A.; Kuznetsova, T.A.; Besednova, N.N.; Shevchenko, N.M.; Zvyagintseva, T.N. Pharmacodynamic parameters of anticoagulants based on sulfated polysaccharides from marine algae. Bull. Exp. Biol. Med. 2006, 142, 591-593. [CrossRef]

94. Yuan, H.; Song, J. Preparation, structural characterization and in vitro antitumor activity of kappa-carrageenan oligosaccharide fraction from Kappaphycus striatum. J. Appl. Phycol. 2005, 17, 7-13. [CrossRef]

95. Ferdouse, F.; Holdt, S.L.; Smith, R.; Murúa, P.; Yang, Z. The Global Status of Seaweed Production, Trade and Utilization. Available online: http:/ / www.fao.org/3/CA1121EN/ca1121en.pdf (accessed on 15 June 2021).

96. de Almeida, C.L.F.; Falcão, D.S.H.; Lima, D.M.G.R.; Montenegro, D.A.C.; Lira, N.S.; de Athayde-Filho, P.F.; Rodrigues, L.C.; de Souza, M.F.V.; Barbosa-Filho, J.M.; Batista, L.M. Bioactivities from marine algae of the genus Gracilaria. Int. J. Mol. Sci. 2011, 12, 4550-4573. [CrossRef]

97. Patra, S.; Muthuraman, M.S. Gracilaria edulis extract induces apoptosis and inhibits tumor in Ehrlich Ascites tumor cells in vivo. BMC Complement. Altern. Med. 2013, 13. [CrossRef] [PubMed]

98. Gunathilaka, T.L.; Samarakoon, K.W.; Ranasinghe, P.; Peiris, L.C.D. In-Vitro Antioxidant, Hypoglycemic Activity, and Identification of Bioactive Compounds in Phenol-Rich Extract from the Marine Red Algae Gracilaria edulis (Gmelin) Silva. Molecules 2019, 24, 3708. [CrossRef]

99. Tannoury, M.Y.; Saab, A.M.; Elia, J.M.; Harb, N.N.; Makhlouf, H.Y.; Diab-Assaf, M. In vitro cytotoxic activity of Laurencia papillosa, marine red algae from the Lebanese coast. J. Appl. Pharm. Sci. 2017, 7, 175-179. [CrossRef]

100. Millet, J.K.; Séron, K.; Labitt, R.N.; Danneels, A.; Palmer, K.E.; Whittaker, G.R.; Dubuisson, J.; Belouzard, S. Middle East respiratory syndrome coronavirus infection is inhibited by griffithsin. Antiviral Res. 2016, 133, 1-8. [CrossRef] [PubMed]

101. Zumla, A.; Chan, J.F.W.; Azhar, E.I.; Hui, D.S.C.; Yuen, K.Y. Coronaviruses-drug discovery and therapeutic options. Nat. Rev. Drug Discov. 2016, 15, 327-347. [CrossRef] 
102. Tanna, B.; Choudhary, B.; Mishra, A. Metabolite profiling, antioxidant, scavenging and anti-proliferative activities of selected tropical green seaweeds reveal the nutraceutical potential of Caulerpa spp. Algal Res. 2018, 36, 96-105. [CrossRef]

103. Paul, N.A.; Neveux, N.; Magnusson, M.; de Nys, R. Comparative production and nutritional value of "sea grapes"-The tropical green seaweeds Caulerpa lentillifera and C. racemosa. J. Appl. Phycol. 2014, 26, 1833-1844. [CrossRef]

104. Mhatre, A.; Gore, S.; Mhatre, A.; Trivedi, N.; Sharma, M.; Pandit, R.; Anil, A.; Lali, A. Effect of multiple product extractions on bio-methane potential of marine macrophytic green alga Ulva lactuca. Renew. Energy 2019, 132, 742-751. [CrossRef]

105. Kalavathy, G.; Baskar, G. Synergism of clay with zinc oxide as nanocatalyst for production of biodiesel from marine Ulva lactuca. Bioresour. Technol. 2019, 281, 234-238. [CrossRef]

106. Ishwarya, R.; Vaseeharan, B.; Kalyani, S.; Banumathi, B.; Govindarajan, M.; Alharbi, N.S.; Kadaikunnan, S.; Al-anbr, M.N.; Khaled, J.M.; Benelli, G. Facile. Green synthesis of zinc oxide nanoparticles using Ulva lactuca seaweed extract and evaluation of their photocatalytic, antibiofilm and insecticidal activity. J. Photochem. Photobiol. B Biol. 2018, 178, 249-258. [CrossRef]

107. Celikler, S.; Yildiz, G.; Vatan, O.; Bilaloglu, R. In vitro antigenotoxicity of Ulva rigida C. Agardh (Chlorophyceae) extract against induction of chromosome aberration, sister chromatid exchange and micronuclei by mutagenic agent MMC. Biomed. Environ. Sci. 2008, 21, 492-498. [CrossRef]

108. Celikler, S.; Tas, S.; Vatan, O.; Ziyanok-Ayvalik, S.; Yildiz, G.; Bilaloglu, R. Anti-hyperglycemic and antigenotoxic potential of Ulva rigida ethanolic extract in the experimental diabetes mellitus. Food Chem. Toxicol. 2009, 47, 1837-1840. [CrossRef] [PubMed]

109. Ramu Ganesan, A.; Shanmugam, M.; Bhat, R. Producing novel edible films from semi refined carrageenan (SRC) and ulvan polysaccharides for potential food applications. Int. J. Biol. Macromol. 2018, 112, 1164-1170. [CrossRef]

110. Mendes, G.D.S.; Soares, A.R.; Martins, F.O.; De Albuquerque, M.C.M.; Costa, S.S.; Yoneshigue-Valentin, Y.; Gestinari, L.M.D.S.; Santos, N.; Romanos, M.T.V. Antiviral activity of the green marine alga Ulva fasciata on the replication of human metapneumovirus. Rev. Inst. Med. Trop. Sao Paulo 2010, 52, 3-10. [CrossRef]

111. Dörschmann, P.; Klettner, A. Fucoidans as potential therapeutics for age-related macular degeneration-current evidence from in vitro research. Int. J. Mol. Sci. 2020, 21, 1-19. [CrossRef]

112. Ustyuzhanina, N.E.; Ushakova, N.A.; Zyuzina, K.A.; Bilan, M.I.; Elizarova, A.L.; Somonova, O.V.; Madzhuga, A.V.; Krylov, V.B.; Preobrazhenskaya, M.E.; Usov, A.I.; et al. Influence of fucoidans on hemostatic system. Mar. Drugs 2013, 11, $2444-2458$. [CrossRef] [PubMed]

113. Jang, J.Y.; Moon, S.Y.; Joo, H.G. Differential effects of fucoidans with low and high molecular weight on the viability and function of spleen cells. Food Chem. Toxicol. 2014, 68, 234-238. [CrossRef]

114. Liang, Z.; Zheng, Y.; Wang, J.; Zhang, Q.; Ren, S.; Liu, T.; Wang, Z.; Luo, D. Low molecular weight fucoidan ameliorates streptozotocin-induced hyper-responsiveness of aortic smooth muscles in type 1 diabetes rats. J. Ethnopharmacol. 2016, 191, 341-349. [CrossRef] [PubMed]

115. Zhang, Z.; Till, S.; Jiang, C.; Knappe, S.; Reutterer, S.; Scheiflinger, F.; Szabo, C.M.; Dockal, M. Structure-activity relationship of the pro- and anticoagulant effects of Fucus vesiculosus fucoidan. Thromb. Haemost. 2013, 111, 429-437. [CrossRef]

116. Yang, C.; Chung, D.; Shin, I.-S.; Lee, H.; Kim, J.; Lee, Y.; You, S. Effects of molecular weight and hydrolysis conditions on anticancer activity of fucoidans from sporophyll of Undaria pinnatifida. Int. J. Biol. Macromol. 2008, 43, 433-437. [CrossRef]

117. Wijesekara, I.; Pangestuti, R.; Kim, S.-K.K. Biological activities and potential health benefits of sulfated polysaccharides derived from marine algae. Carbohydr. Polym. 2011, 84, 14-21. [CrossRef]

118. Irhimeh, M.R.; Fitton, J.H.; Lowenthal, R.M. Pilot clinical study to evaluate the anticoagulant activity of fucoidan. Blood Coagul. Fibrinolysis 2009, 20, 607-610. [CrossRef] [PubMed]

119. Myers, S.P.; Mulder, A.M.; Baker, D.G.; Robinson, S.R.; Rolfe, M.I.; Brooks, L.; Fitton, J.H. Effects of fucoidan from Fucus vesiculosus in reducing symptoms of osteoarthritis: A randomized placebo-controlled trial. Biol. Targets Ther. 2016, 10, 81-88. [CrossRef]

120. Pozharitskaya, O.N.; Shikov, A.N.; Faustova, N.M.; Obluchinskaya, E.D.; Kosman, V.M.; Vuorela, H.; Makarov, V.G. Pharmacokinetic and tissue distribution of fucoidan from Fucus vesiculosus after oral administration to rats. Mar. Drugs 2018, 16, 1-10. [CrossRef] [PubMed]

121. Thomas, N.V.; Kim, S.K. Potential pharmacological applications of polyphenolic derivatives from marine brown algae. Environ Toxicol. Pharmacol. 2011, 32, 325-335. [CrossRef]

122. Khalid, S.; Abbas, M.; Saeed, F.; Bader-Ul-Ain, H.; Suleria, H.A.R. Therapeutic Potential of Seaweed Bioactive Compounds; IntechOpen: London, UK, 2018.

123. Yende, S.; Harle, U.; Chaugule, B. Therapeutic potential and health benefits of Sargassum species. Pharmacogn. Rev. 2014, 8, 1-7. [CrossRef]

124. Barbosa, M.; Valentão, P.; Andrade, P.B. Bioactive compounds from macroalgae in the new millennium: Implications for neurodegenerative diseases. Mar. Drugs 2014, 12, 4934-4972. [CrossRef]

125. Tomori, M.; Nagamine, T.; Miyamoto, T.; Iha, M. Evaluation of the immunomodulatory effects of fucoidan derived from Cladosiphon okamuranus tokida in mice. Mar. Drugs 2019, 17, 547. [CrossRef]

126. Yang, W.; Yu, X.; Zhang, Q.; Lu, Q.; Wang, J.; Cui, W.; Zheng, Y.; Wang, X.; Luo, D. Attenuation of streptozotocin-induced diabetic retinopathy with low molecular weight fucoidan via inhibition of vascular endothelial growth factor. Exp. Eye Res. 2013, 115, 96-105. [CrossRef] [PubMed]

127. Trinchero, J.; Ponce, N.M.A.; Córdoba, O.L.; Flores, M.L.; Pampuro, S.; Stortz, C.A.; Salomón, H.; Turk, G. Antiretroviral Activity of Fucoidans Extracted from the Brown Seaweed Adenocystis utricularis. Phyther. Res. 2009, 23, 707-712. [CrossRef] 
128. Younes, M.; Aggett, P.; Aguilar, F.; Crebelli, R.; Filipič, M.; Frutos, M.J.; Galtier, P.; Gott, D.; Gundert-Remy, U.; Kuhnle, G.G.; et al. Re-evaluation of carrageenan (E 407) and processed Eucheuma seaweed (E 407a) as food additives. EFSA J. 2018, 16. [CrossRef]

129. Mortensen, A.; Aguilar, F.; Crebelli, R.; Di Domenico, A.; Frutos, M.J.; Galtier, P.; Gott, D.; Gundert-Remy, U.; Lambré, C.; Leblanc, J.; et al. Re-evaluation of agar (E 406) as a food additive. EFSA J. 2016, 14. [CrossRef]

130. Imeson, A. Food Stabilisers, Thickeners and Gelling Agents; Wiley: Hoboken, NJ, USA, 2009; ISBN 9781405132671.

131. Gonçalves, A.M.M. Sustainable Premium Ready Meals for a Daily Nutritional Diet: Human Population Growing Demand; Springer Nature Switzerland: Cham, Switzerland, 2021.

132. Pereira, L.; Correia, F. Macroalgas Marinhas da Costa Portuguesa- Biodiversidade, Ecologia e Utilizações. Paris: Nota de Rodapé Edições; BNP Publishing: Troy, MI, USA, 2015.

133. Cho, M.; Lee, H.S.; Kang, I.J.; Won, M.H.; You, S. Antioxidant properties of extract and fractions from Enteromorpha prolifera, a type of green seaweed. Food Chem. 2011, 127, 999-1006. [CrossRef] [PubMed]

134. Kraan, S. Algal Polysaccharides, Novel Application, and Outlook; IntechOpen: London, UK, 2012.

135. Hoppe, H.A.; Levring, T.; Tanaka, Y. Marine Algae and Their Products and Constituents in Pharmacy; AGRIS (FAO): Rome, Italy, 1979.

136. Myers, S.P.; O'Connor, J.; Fitton, J.H.; Brooks, L.; Rolfe, M.; Connellan, P.; Wohlmuth, H.; Cheras, P.A.; Morris, C. A combined Phase I and II open-label study on the Immunomodulatory effects of seaweed extract nutrient complex. Biol. Targets Ther. 2011, 5, 45-60. [CrossRef]

137. Houghton, P.J.; Hylands, P.J.; Mensah, A.Y.; Hensel, A.; Deters, A.M. In vitro tests and ethnopharmacological investigations: Wound healing as an example. J. Ethnopharmacol. 2005, 100, 100-107. [CrossRef]

138. EMA. Community herbal monograph on Fucus vesiculosus L., thallus; EMA: Amsterdam, The Netherlands, 2012.

139. Hong, D.D.; Hien, H.M.; Son, P.N. Seaweeds from Vietnam used for functional food, medicine and biofertilizer. J. Appl. Phycol. 2007, 19, 817-826. [CrossRef]

140. Alarif, W.M.; Al-Lihaibi, S.S.; Ayyad, S.E.N.; Abdel-Rhman, M.H.; Badria, F.A. Laurene-type sesquiterpenes from the Red Sea red alga Laurencia obtusa as potential antitumor-antimicrobial agents. Eur. J. Med. Chem. 2012, 55, 462-466. [CrossRef]

141. Cho, S.; Kim, S.K. Neuropharmacological properties of marine plants. In Marine Pharmacognosy: Trends and Applications; Taylor \& Francis: Boca Raton, FL, USA, 2012.

142. Lin, M.T.; Beal, M.F. Mitochondrial dysfunction and oxidative stress in neurodegenerative diseases. Nature 2006, 443, 787-795. [CrossRef]

143. Bauer, S.; Jin, W.; Zhang, F.; Linhardt, R.J. The Application of Seaweed Polysaccharides and Their Derived Products with Potential for the Treatment of Alzheimer's Disease. Mar. Drugs 2021, 19, 89. [CrossRef]

144. Park, S.K.; Kang, J.Y.; Kim, J.M.; Yoo, S.K.; Han, H.J.; Chung, D.H.; Kim, D.O.; Kim, G.H.; Heo, H.J. Fucoidan-Rich Substances from Ecklonia cava Improve Trimethyltin-Induced Cognitive Dysfunction via Down-Regulation of Amyloid $\beta$ Production/Tau Hyperphosphorylation. Mar. Drugs 2019, 17, 591. [CrossRef] [PubMed]

145. Bogie, J.; Hoeks, C.; Schepers, M.; Tiane, A.; Cuypers, A.; Leijten, F.; Chintapakorn, Y.; Suttiyut, T.; Pornpakakul, S.; Struik, D.; et al. Dietary Sargassum fusiforme improves memory and reduces amyloid plaque load in an Alzheimer's disease mouse model. Sci. Rep. 2019, 9, 1-16. [CrossRef]

146. Myung, C.S.; Shin, H.C.; Hai, Y.B.; Soo, J.Y.; Bong, H.L.; Jong, S.K. Improvement of memory by dieckol and phlorofucofuroeckol in ethanol-treated mice: Possible involvement of the inhibition of acetylcholinesterase. Arch. Pharm. Res. 2005, 28, 691-698. [CrossRef] [PubMed]

147. Ahn, B.R.; Moon, H.E.; Kim, H.R.; Jung, H.A.; Choi, J.S. Neuroprotective effect of edible brown alga Eisenia bicyclis on amyloid beta peptide-induced toxicity in PC12 cells. Arch. Pharm. Res. 2012, 35, 1989-1998. [CrossRef]

148. Liu, Y.; Jiang, L.; Li, X. K-carrageenan-derived pentasaccharide attenuates A 325 -35-induced apoptosis in SH-SY5Y cells via suppression of the JNK signaling pathway. Mol. Med. Rep. 2017, 15, 285-290. [CrossRef] [PubMed]

149. Wang, L.; Oh, J.Y.; Je, J.G.; Jayawardena, T.U.; Kim, Y.S.; Ko, J.Y.; Fu, X.; Jeon, Y.J. Protective effects of sulfated polysaccharides isolated from the enzymatic digest of Codium fragile against hydrogen peroxide-induced oxidative stress in in vitro and in vivo models. Algal Res. 2020, 48, 101891. [CrossRef]

150. Damonte, E.; Matulewicz, M.; Cerezo, A. Sulfated Seaweed Polysaccharides as Antiviral Agents. Curr. Med. Chem. 2004, 11, 2399-2419. [CrossRef]

151. Carvalho, G. de Azevedo, T.; Bezerra, M.E.B.; Santos, M. da G. de L.; Souza, L.A.; Marques, C.T.; Benevides, N.M.B.; Leite, E.L. Heparinoids algal and their anticoagulant, hemorrhagic activities and platelet aggregation. Biomed. Pharmacother. 2009, 63, 477-483. [CrossRef]

152. Pozharitskaya, O.N.; Obluchinskaya, E.D.; Shikov, A.N. Mechanisms of Bioactivities of Fucoidan from the Brown Seaweed Fucus vesiculosus L. of the Barents Sea. Mar. Drugs 2020, 18, 1-17. [CrossRef] [PubMed]

153. Kang, J.Y.; Khan, M.N.A.; Park, N.H.; Cho, J.Y.; Lee, M.C.; Fujii, H.; Hong, Y.K. Antipyretic, analgesic, and anti-inflammatory activities of the seaweed Sargassum fulvellum and Sargassum thunbergii in mice. J. Ethnopharmacol. 2008, 116, 187-190. [CrossRef]

154. De Zoysa, M.; Nikapitiya, C.; Jeon, Y.J.; Jee, Y.; Lee, J. Anticoagulant activity of sulfated polysaccharide isolated from fermented brown seaweed Sargassum fulvellum. J. Appl. Phycol. 2008, 20, 67-74. [CrossRef]

155. Gwon, W.G.; Lee, M.S.; Kim, J.S.; Kim, J.I.; Lim, C.W.; Kim, N.G.; Kim, H.R. Hexane fraction from Sargassum fulvellum inhibits lipopolysaccharide- induced inducible nitric oxide synthase expression in RAW 264.7 cells via NF-kB pathways. Am. J. Chin. Med. 2013, 41, 565-584. [CrossRef] [PubMed] 
156. Hannan, M.A.; Kang, J.Y.; Hong, Y.K.; Lee, H.S.; Chowdhury, M.T.H.; Choi, J.S.; Choi, I.S.; Moon, I.S. A brown alga Sargassum fulvellum facilitates neuronal maturation and synaptogenesis. Vitr. Cell. Dev. Biol. Anim. 2012, 48, 535-544. [CrossRef]

157. Shi, Q.; Wang, A.; Lu, Z.; Qin, C.; Hu, J.; Yin, J. Overview on the antiviral activities and mechanisms of marine polysaccharides from seaweeds. Carbohydr. Res. 2017, 453-454, 1-9. [CrossRef] [PubMed]

158. Gheda, S.F.; El-Adawi, H.I.; El-Deeb, N.M. Antiviral Profile of Brown and Red Seaweed Polysaccharides Against Hepatitis C Virus. Iran. J. Pharm. Res. IJPR 2016, 15, 483-491. [PubMed]

159. Santos, M.G.M.; Lagrota, M.H.C.; Miranda, M.M.F.S.; Yoneshigue-Valentin, Y.; Wigg, M.D. A screening for the antiviral effect of extracts from Brazilian marine algae against acyclovir resistant herpes simplex virus type 1. Bot. Mar. 1999, 42, 227-230. [CrossRef]

160. Soares, A.R.; Robaina, M.C.S.; Mendes, G.S.; Silva, T.S.L.; Gestinari, L.M.S.; Pamplona, O.S.; Yoneshigue-Valentin, Y.; Kaiser, C.R.; Romanos, M.T.V. Antiviral activity of extracts from Brazilian seaweeds against herpes simplex virus. Brazilian J. Pharmacogn. 2012, 22, 714-723. [CrossRef]

161. Lakshmi, V.; Goel, A.K.; Srivastava, M.N.; Raghubir, R. Bioactivity of marine organisms: Part X - Screening of some marine fauna from the Indian coasts. Indian J. Exp. Biol. 2006, 44, 754-756. [CrossRef]

162. Gerber, P.; Dutcher, J.D.; Adams, E.V.; Sherma, J.H. Protective Effect of Seaweed Extracts for Chicken Embryos Infected with Influenza B or Mumps Virus. Proc. Soc. Exp. Biol. Med. 1958, 590-593. [CrossRef]

163. Pereira, L. Identification of phycocolloids by vibrational spectroscopy. In World Seaweed Resources-An Authoritative Reference System; ETI Information Services Ltd.: Amsterdam, The Netherlands, 2006.

164. Kwon, P.S.; Oh, H.; Kwon, S.-J.; Jin, W.; Zhang, F.; Fraser, K.; Hong, J.J.; Linhardt, R.J.; Dordick, J.S. Sulfated polysaccharides effectively inhibit SARS-CoV-2 in vitro. Cell Discov. 2020, 6, 50. [CrossRef] [PubMed]

165. Pereira, L.; Critchley, A.T. The COVID 19 novel coronavirus pandemic 2020: Seaweeds to the rescue? Why does substantial, supporting research about the antiviral properties of seaweed polysaccharides seem to go unrecognized by the pharmaceutical community in these desperate times? J. Appl. Phycol. 2020, 32, 1875-1877. [CrossRef]

166. Kim, S.K.; Ravichandran, Y.D.; Khan, S.B.; Kim, Y.T. Prospective of the cosmeceuticals derived from marine organisms. Biotechnol. Bioprocess Eng. 2008, 13, 511-523. [CrossRef]

167. Skjånes, K.; Rebours, C.; Lindblad, P. Potential for green microalgae to produce hydrogen, pharmaceuticals and other high value products in a combined process. Crit. Rev. Biotechnol. 2013, 33, 172-215. [CrossRef]

168. Mukherjee, P.K.; Maity, N.; Nema, N.K.; Sarkar, B.K. Bioactive compounds from natural resources against skin aging. Phytomedicine 2011, 19, 64-73. [CrossRef]

169. Fransiska, D.; Darmawan, M.; Sinurat, E.; Sedayu, B.B.; Wardhana, Y.W.; Herdiana, Y.; Setiana, G.P. Characteristics of Oil in Water (o/w) Type Lotions Incorporated with Kappa/Iota Carrageenan. IOP Conf. Ser. Earth Environ. Sci. 2021, 715, 012050. [CrossRef]

170. Lakshmi, D.S.; Sankaranarayanan, S.; Gajaria, T.K.; Li, G.; Kujawski, W.; Kujawa, J.; Navia, R. A short review on the valorization of green seaweeds and ulvan: Feedstock for chemicals and biomaterials. Biomolecules 2020, 10, 991. [CrossRef]

171. Tziveleka, L.A.; Ioannou, E.; Roussis, V. Ulvan, a bioactive marine sulphated polysaccharide as a key constituent of hybrid biomaterials: A review. Carbohydr. Polym. 2019, 218, 355-370. [CrossRef] [PubMed]

172. Ebrahimi, A.; Hashemi, S.; Akbarzadeh, S.; Ramavandi, B. Modification of green algae harvested from the Persian Gulf by L-cysteine for enhancing copper adsorption from wastewater: Experimental data. Chem. Data Collect. 2016, 2, 36-42. [CrossRef]

173. Guidara, M.; Yaich, H.; Richel, A.; Blecker, C.; Boufi, S.; Attia, H.; Garna, H. Effects of extraction procedures and plasticizer concentration on the optical, thermal, structural and antioxidant properties of novel ulvan films. Int. J. Biol. Macromol. 2019, 135, 647-658. [CrossRef] [PubMed]

174. Soares, C.; Švarc-Gajić, J.; Oliva-Teles, M.T.; Pinto, E.; Nastić, N.; Savić, S.; Almeida, A.; Delerue-Matos, C. Mineral Composition of Subcritical Water Extracts of Saccorhiza polyschides, a Brown Seaweed Used as Fertilizer in the North of Portugal. J. Mar. Sci. Eng. 2020, 8, 244. [CrossRef]

175. Nkemka, V.N.; Murto, M. Evaluation of biogas production from seaweed in batch tests and in UASB reactors combined with the removal of heavy metals. J. Environ. Manag. 2010, 91, 1573-1579. [CrossRef] [PubMed]

176. Sharma, H.S.S.; Fleming, C.; Selby, C.; Rao, J.R.; Martin, T. Plant biostimulants: A review on the processing of macroalgae and use of extracts for crop management to reduce abiotic and biotic stresses. J. Appl. Phycol. 2014, 26, 465-490. [CrossRef]

177. Rengasamy, K.R.R.; Kulkarni, M.G.; Papenfus, H.B.; Van Staden, J. Quantification of plant growth biostimulants, phloroglucinol and eckol, in four commercial seaweed liquid fertilizers and some by-products. Algal Res. 2016, 20, 57-60. [CrossRef]

178. Wells, M.L.; Potin, P.; Craigie, J.S.; Raven, J.A.; Merchant, S.S.; Helliwell, K.E.; Smith, A.G.; Camire, M.E.; Brawley, S.H. Algae as nutritional and functional food sources: Revisiting our understanding. J. Appl. Phycol. 2017, 29, 949-982. [CrossRef]

179. Farid, Y.; Etahiri, S. Activité antimicrobienne des algues marines de la lagune d' Oualidia ( Maroc ): Criblage et optimisation de la période de la récolte. Appl. Biosci. 2009, 1543-1552.

180. Alves, R.C.C.; Figueiredo das Mercês, P.F.; Arruda de Souza, I.R.; Alves de Almeida, C.M.; Sant'Anna da Silva, A.P.; de Menezes Lima, V.L.; dos Santos Correia, M.T.; da Silva, M.V.; da Silva, A.G. Antimicrobial activity of seaweeds of Pernambuco, northeastern coast of Brazil. African J. Microbiol. Res. 2016, 10, 312-318. [CrossRef]

181. Asha, A.; Martin Rathi, J.; Patric Raja, D.; Sahayaraj, K. Biocidal activity of two marine green algal extracts against third instar nymph of Dysdercus cingulatus (Fab.) (Hemiptera: Pyrrhocoridae). J. Biopestic. 2012, 5, 129-134. 
182. Arioli, T.; Mattner, S.W.; Winberg, P.C. Applications of seaweed extracts in Australian agriculture: Past, present and future. J. Appl. Phycol. 2015, 27, 2007-2015. [CrossRef] [PubMed]

183. Raghunandan, B.L.; Vyas, R.V.; Patel, H.K.; JHala, Y.K. Perspectives of Seaweed as Organic Fertilizer in Agriculture. In Soil Fertility Management for Sustainable Development; Springer: Berlin, Germany, 2019; pp. 267-289. ISBN 9789811359040.

184. Saravana, P.S.; Choi, J.H.; Park, Y.B.; Woo, H.C.; Chun, B.S. Evaluation of the chemical composition of brown seaweed (Saccharina japonica) hydrolysate by pressurized hot water extraction. Algal Res. 2016, 13, 246-254. [CrossRef]

185. Ciepiela, G.A.; Godlewska, A.; Jankowska, J. The effect of seaweed Ecklonia maxima extract and mineral nitrogen on fodder grass chemical composition. Environ. Sci. Pollut. Res. 2016, 23, 2301-2307. [CrossRef]

186. Mzibra, A.; Aasfar, A.; El Arroussi, H.; Khouloud, M.; Dhiba, D.; Kadmiri, I.M.; Bamouh, A. Polysaccharides extracted from Moroccan seaweed: A promising source of tomato plant growth promoters. J. Appl. Phycol. 2018, 30, 2953-2962. [CrossRef]

187. Vijayakumar, S.; Durgadevi, S.; Arulmozhi, P.; Rajalakshmi, S.; Gopalakrishnan, T.; Parameswari, N. Effect of seaweed liquid fertilizer on yield and quality of Capsicum annum L. Acta Ecol. Sin. 2019, 39, 406-410. [CrossRef]

188. Paulert, R.; Talamini, V.; Cassolato, J.E.F.; Duarte, M.E.R.; Noseda, M.D.; Smania, A.; Stadnik, M.J. Effects of sulfated polysaccharide and alcoholic extracts from green seaweed Ulva fasciata on anthracnose severity and growth of common bean (Phaseolus vulgaris L.)Die Wirkung von sulfonierten Polysacchariden und alkoholischen Extrakten aus der Grünalge U. J. Plant Dis. Prot. 2009, 116, 263-270. [CrossRef]

189. Cherry, P.; O’Hara, C.; Magee, P.J.; McSorley, E.M.; Allsopp, P.J. Risks and benefits of consuming edible seaweeds. Nutr. Rev. 2019, 77, 307-329. [CrossRef]

190. Makkar, H.P.S.; Tran, G.; Heuzé, V.; Giger-Reverdin, S.; Lessire, M.; Lebas, F.; Ankers, P. Seaweeds for livestock diets: A review. Anim. Feed Sci. Technol. 2016, 212,1-17. [CrossRef]

191. Bach, S.J.; Wang, Y.; McAllister, T.A. Effect of feeding sun-dried seaweed (Ascophyllum nodosum) on fecal shedding of Escherichia coli O157:H7 by feedlot cattle and on growth performance of lambs. Anim. Feed Sci. Technol. 2008, 142, 17-32. [CrossRef]

192. Braden, K.W.; Blanton, J.R.; Allen, V.G.; Pond, K.R.; Miller, M.F. Ascophyllum nodosum supplementation: A preharvest intervention for reducing Escherichia coli O157:H7 and Salmonella spp. in feedlot steers. J. Food Prot. 2004, 67, 1824-1828. [CrossRef]

193. Braden, K.W.; Blanton, J.R.; Montgomery, J.L.; Van Santen, E.; Allen, V.G.; Miller, M.F. Tasco supplementation: Effects on carcass characteristics, sensory attributes, and retail display shelf-life. J. Anim. Sci. 2007, 85, 754-768. [CrossRef] [PubMed]

194. Nagayama, K.; Iwamura, Y.; Shibata, T.; Hirayama, I.; Nakamura, T. Bactericidal activity of phlorotannins from the brown alga Ecklonia kurome. J. Antimicrob. Chemother. 2002, 50, 889-893. [CrossRef]

195. Evans, F.D.; Critchley, A.T. Seaweeds for animal production use. J. Appl. Phycol. 2014, 26, 891-899. [CrossRef]

196. Dierick, N.; Ovyn, A.; De Smet, S. Effect of feeding intact brown seaweed Ascophyllum nodosum on some digestive parameters and on iodine content in edible tissues in pigs. J. Sci. Food Agric. 2009, 89, 584-594. [CrossRef]

197. Soler-Vila, A.; Coughlan, S.; Guiry, M.D.; Kraan, S. The red alga Porphyra dioica as a fish-feed ingredient for rainbow trout (Oncorhynchus mykiss): Effects on growth, feed efficiency, and carcass composition. J. Appl. Phycol. 2009, 21, 617-624. [CrossRef]

198. Ergün, S.; Soyutürk, M.; Güroy, B.; Güroy, D.; Merrifield, D. Influence of Ulva meal on growth, feed utilization, and body composition of juvenile Nile tilapia (Oreochromis niloticus) at two levels of dietary lipid. Aquac. Int. 2009, 17, 355-361. [CrossRef]

199. Güroy, D.; Güroy, B.; Merrifield, D.L.; Ergün, S.; Tekinay, A.A.; Yiğit, M. Effect of dietary Ulva and Spirulina on weight loss and body composition of rainbow trout, Oncorhynchus mykiss (Walbaum), during a starvation period. J. Anim. Physiol. Anim. Nutr. 2011, 95, 320-327. [CrossRef]

200. Kamunde, C.; Sappal, R.; Melegy, T.M. Brown seaweed (AquaArom) supplementation increases food intake and improves growth, antioxidant status and resistance to temperature stress in Atlantic salmon, Salmo salar. PLoS ONE 2019, 14, 1-24. [CrossRef] 